\title{
The making of the USA PATRIOT ACT I: \\ The Legislative Process and Dynamics
}

\author{
Kam C. Wong, J.D., Ph.D. ${ }^{1}$ \\ 24301
}

September 20, 2005

\section{All rights reserved. Article under publication review. Not to be cited without express permission from the author.}

\footnotetext{
${ }^{1}$ Associate Professor, Department of Public Affairs, University of Wisconsin (Oshkosh). B.A. (Hons.), J.D. (Indiana); Diploma (N.I.T.A. - Northwestern); M.A., Ph.D. (SUNY Albany - Criminal Justice); vice-Chair, Hong Kong Society of Criminology; Associate Fellow, Center of Criminology, University of Hong Kong, vice-President (2001-2), President (2002-3) AAPS (Asian Association of Police Studies). Managing Editor, Police Practice and Research: An International Journal. His articles appeared in Criminal Law Bulletin; Georgetown Journal of Law and Public Policy; Columbia Journal of Asian Law; British Journal of Criminology; Journal of Information Law \& Technology (JILT); Pacific Rim Law \& Policy Journal; International Journal of the Sociology of Law; Australian Journal of Law and Society; Australian and New Zealand Journal of Criminology; John Marshall Journal of Computer and Information Law, and others
} 


\section{ABSTRACT}

On September 11, 2001, terrorists attacked America without warning, killing 2752 in New York City alone. The President declared war on terrorism and pledged to use all resources at United States' disposal to conquer the enemy. On October 26, 2001, President Bush signed into law the USA PATRIOT ACT, giving the law enforcement officials expansive powers and security agencies increased resources to fight terrorism, at home and abroad.

A cursory review of the legal literature shows that the USA PATRIOT ACT was "rushed" passed Congress by the Bush administration without following the usual legislative procedure. Throughout the entire legislative process, neither the Congress nor the Administration has systematically investigated and critically debated the merit - necessity and efficacy, costs and benefits, and the impact and implications of the ACT on the Constitution, on the society, on the people. More mystifyingly, neither the general public nor the mass media took the government to task for a want of due diligent in scrutinizing the ACT. How could this have happened? To date, no serious attempt has been made to explain how and why the USA PATRIOT ACT was adopted without any serious context and effective challenge. This is a first attempt to do so.

This article, based on a larger research project ("The Impact and Implications of USA PATRIOT Act on American Society.") investigated into the legislative history of the USA PATRIOT ACT, broadly define. This article is first of a two part series reporting upon: "The Making of the USA PATRIOT ACT". It is subtitled: "Legislative Process and Dynamics". The article to follow is subtitled: "Legislative Climate and Political Context."

This article examined the Congressional records, tracked the floor debates and monitored newspaper accounts to document the process and detail the dynamics as to how the USA PATRIOT ACT was passed. The subsequent article would be looking into the historical context, political climate, social circumstances, and cultural milieu to ascertain why the USA PATRIOT ACT was made in the way and manner it did. 


\section{The making of the USA PATRIOT ACT I: The Legislative Process and Dynamics}

"Those who would give up essential liberty to purchase a little temporary safety deserves neither liberty nor safety."

Benjamin Franklin

\section{Introduction}

On September 11, 2001, terrorists attacked America without warning, killing 2752 in New York City alone. ${ }^{2}$ On September 12, 2001, the President declared war on terrorism, pledging: "United States of America will use all our sources to conquer this enemy.", On October 26, 2001, President Bush signed into law the USA PATRIOT ACT, ${ }^{4}$ giving the law enforcement officials expansive powers and the security agencies increased resources to fight terrorism, at home and abroad. ${ }^{5}$

A cursory review of the legal literature ${ }^{6}$ shows that the USA PATRIOT Act was "rushed" passed Congress by the Bush administration without following

\footnotetext{
2 There are conflicting accounts on the number of death toll to 9/11. The figure cited here is based on the most recent accounting of confirmed dead. See "2,752: World Trade Center Death Toll Shrinks By 40," WNBC.com October 30, 2003. The other account is 2819 deaths, "9/11 by the Numbers" New York Magazine http://www.newyorkmetro.com/news/articles/wtc/1year/numbers.htm Altogether, the FBI reported 3,047 victims resulting from the terrorist attacks on September 11, 2001: 2,175 males and 648 females died at the World Trade Center; 108 males and 71 females died at the Pentagon; and 20 males and 20 females died in the plane crash in Somerset County, PA. Seventy-one law enforcement officers were killed in the line of duty at a result of the attacks on the World Trade Center. (Federal Bureau of Investigation. 2002. Uniform Crime Reports: Crime in the United States 2001. (Washington DC: U.S. Department of Justice.)

3 "Remarks By The President In Photo Opportunity With The National Security Team," The Cabinet Room, 10:53 A.M. EDT. The White House, Office of the Press Secretary, September 12, 2001. http://usinfo.state.gov/topical/pol/terror/01091208.htm

${ }^{4}$ USA PATRIOT Act, October 26, 2001, P. L.107-056; 115 STAT. 272.

${ }^{5}$ For legal analysis, see Charles Doyle, "The USA PATRIOT Act: A Legal Analysis," Congressional Research Service, April 15, 2002.

${ }^{6}$ A recent systematic biographic search by a law librarian uncovered only one entry having to do the legislative history of USA PATRIOT ACT, i.e. Beryl A. Howell, "Seven Weeks: The Making of the USA PATRIOT Act," 72 Geo. Wash. L. Rev. 1145 (2004). Howell benefited from being an insider to the legislative process. He worked for
} 
the usual legislative procedure, i.e., agency review, ${ }^{7}$ public hearings,${ }^{8}$ mark up, ${ }^{9}$ floor debate, ${ }^{10}$ and conference report, ${ }^{11}$ in both chambers. ${ }^{12}$ More

Senator Leahy, then the Chairman of the Senate Judiciary Committee. See Kate Dixon, "The U.S.A. PATRIOT Act: A Selected Bibliography," Research Librarian Western New England College School of Law Library. April 2005. The author's independent research by author showed that there was no authoritative account on the legislative history of Anti-Terrorism Act of 2001 and USA PATRIOT ACT. The data relied upon for this research came from the following sources. For a brief, but informative, account of how the Act was rushed through Congress, see the investigative report of Robert O' Harrow Jr. (with assistance from the Center for Investigative Reporting) "Six Weeks in Autumn," Washington Post. Sunday, October 27, 2002; Page W06 (The Patriot Act was rushed through Congress by the administration under the stewardship of Ashcroft.) For a day to day account of anti-terrorism legislative activities in the Congress, see Tech Law Journal Daily E-Mail Alert http://www.techlawjournal.com/welcome.htm For a detail description of the passage of the Patriot Act, see James Bovard, Terrorism and Tyranny: Trampling Freedom, Justice, and Peace to Rid the World of Evil (Palgrave Macmillan, 2003), esp. Chapter 4: "Patriot Railroad." For a compilation of legislative materials, see Bernard D., Jr. Reams and Christopher Anglim (Editors), USA Patriot Act: A Legislative History of the Uniting and Strengthening America by Providing Appropriate Tools Required to Intercept and Obstruct Terrorism Act (Fred B Rothman \& Co, 2002). For a summary of the process, see "Introduction", Id. For an inside the beltway account of the legislative process, see "USA PATRIOT Act: A Summary of ALA Activities," ALA Washington Office, Jan.19, 2002. For an electronic library of key legislative documents, consult "Legislative History of the USA PATRIOT Act," Center for Democracy and Technology. For critical events in the passage of the USA PATRIOT ACT, see Steven Brill, "WHAT PRICE FREEDOM? The day the Constitution died," Capitol Hill Blue March 3, 2003. http://chblue.com/artman/publish/printer_1865.shtml

${ }^{7}$ Morton H. Halperin, "Less Secure, Less Free, " American Prospect Vol. 12, No. 20, Nov. 19, 2001. http://www.prospect.org/print/V12/20/halperin-m.html (The Administration original anti-terrorism measures (CTA - ATA - MTA) was the handmaiden of the Attorney General (AG) staff, alone. The Office of Budget Management (OBM) was intentionally by passed to deny and avoid input and comments from agencies.)

${ }^{8}$ There were two hearings being held, one on September 25, 2001 when AG Ashcroft was invited to answer questions on Administration's anti-terrorism proposals (MATA ATA). The Senate Committee on the Judiciary held a hearing on Tuesday, September 25, 2001, at 10:00 a.m. on "Homeland Defense." Presided by Chairman Leahy. The other was called by Senator Feingold who called a public hearing on October 3, 2001 to discuss the civil liberties implications of the PATRIOT ACT and related anti-terrorism measures. The Senate Judiciary Committee's Subcommittee on the Constitution, Federalism, and Property Rights held a hearing titled "Protecting Constitutional Freedoms in the Face of Terrorism." Presided by Sen. Russ Feingold (D-WI)

${ }^{9}$ Morton H. Halperin, "The Liberties We Defend," American Prospect Vol. 12, No. 18 Oct. 22, 2001. http://www.prospect.org/print/V12/18/halperin-m-2.html ("Four key Republicans on the House Judiciary Committee wrote to their chairman questioning the 
significantly, throughout the entire USA PATRIOT Act legislative process, neither the Congress nor the Administration has systematically investigated, judiciously examined, openly debated, and comprehensively considered the relative merits and utilities - necessity and efficacy, costs and benefits - and the impact and implication - long and short, direct and indirect - of the $\mathrm{ACT}$ on the Constitution, ${ }^{13}$ on the society, on the people. In fact, it is fair to

rush to mark up a bill (MATA) after only one hearing with the attorney general (9/25/01). "What we must avoid," they declared, "is the impulse to hastily approve wholesale changes to search and seizure, surveillance, immigration and other laws in an understandable but misguided attempt to thwart future attacks.")

${ }^{10}$ Floor debate was limited to 4 hours for USA ACT. Congressional Record: October 11, 2001 (Senate) Page S10547-S10630 The debate was less a debate as it was an opportunity to put things on the record, i.e. to detail the content and describe the process (Senator Leahy started by observing that the Bill was not to anyone's liking); list the concessions and catalogue the (negotiated) achievements (Senate Leady spent most of the time allotted explaining various provisions); leave a legislative record anticipating Supreme Court challenges ahead (Senate Specter (R-PA). See also Beryl A. Howell, "Seven Weeks: The Making of the USA PATRIOT Act," 72 Geo. Wash. L. Rev. 1145 (2004). (From the beginning to the end, the anti-terrorism legislation was orchestrated for passage by the Administration, not open for debate by the public or subject to scrutiny of the Congress. In the final USA ACT debate, the Senate leadership from both parties made it known that that the USA ACT was not to be changed. No floor amendments were allowed, save for three by Senator Feingold. Dissenters were shunned, lest they undo the hard fought and long struggled compromise.)

${ }^{11}$ Beryl A. Howell, "Seven Weeks: The Making of the USA PATRIOT Act," 72 Geo. Wash. L. Rev. 1145 (2004). (House and Senate Conference on PATRIOT ACT and USA ACT was done away with because the Bush Administration in general and AG Ashcroft in particular was afraid that the conference leadership (as then constituted) might jeopardize the chance of passage.).

${ }^{12}$ For process in the Senate, see "Guide to Senate Legislative Processes" (Congressional Research Service, Feb. 2002). For process in the House, see HOW OUR LAWS ARE MADE, Revised and Updated by Charles W. Johnson, Parliamentarian, United States House of Representatives (Last update: Thu, 06 Jan 2005 18:49:22 GMT).

${ }^{13}$ There were some concerned expressed by some vocal member of the House and Senate, e.g. Leahy Feingold, and a coalition of interested parties, e.g. ACLU and EFF, over he dire consequences of the ACT on civil liberties. But these voices were intentionally suppressed and conveniently ignored. As a result there was no serious debate over the long term impact and implications of the ACT on the Constitutional, e.g. how our democratic institutions and rule of law culture might changed in the wage of 9/11, domestically and internationally. As it turned out from hindsight, 9/11 was a watershed event. The war on terror has changed international opinion about US democratic institutions and domestic attitude towards law and order. For intentional opinion, see "Global Opinion: The Spread of Anti-Americanism A review of Pew Global Attitudes Project findings," January 24, 2005 (Increasingly the world - friends and foes 
say, as other knowledgeable insiders have observed, that the USA PATRIOT ACT was entirely a Bush administration brainchild, conceived by the AG, imposed on the Congress ${ }^{14}$ and fed to the American people in a time of crisis $^{15}$ and with the use of high handed tactics. ${ }^{16}$ How could that have happened? This is the research question this article seeks to address. To date, no serious attempt has been made to understand how and why the USA PATRIOT ACT was able to rush through Congress without serious contest and effective challenge. ${ }^{17}$ This is a first attempt to do so.

alike - from Europe to Asia, from South America to Africa - has a negative image of America, e.g. in terms of favorable ratings, Britain went from $75 \%$ (summer 2002) to $58 \%$ (Mar. 2004) and Jordon went from $25 \%$ to $5 \%$ in the same period. The sincerity of US war on terrorism was widely questioned in 2004: Britain (41\%), France (61\%), Russia (48\%), Germany (65\%), Turkey (64\%), Morocco (66\%), Jordon (58\%) and Pakistan (58\%). Most significantly, world public opinion about US's commitment to democracy has slipped in 2004 survey: Britain (45\% less committed), France (79\%), Russia (53\%), Germany (70\%), Turkey (73\%), Morocco (66\%), Jordon (56\%) and Pakistan (57\%). For domestic opinion "Americans on Terrorism: Two Years After 9/11," Program on International Policy Attitudes and Knowledge Networks (2003) (By a margin of $52 \%$ vs. $38 \%$, US public surveyed observed that remove of (Constitutional) limitations on government has gone too far.(p.9) Contrary to government policy. A major believed that US citizens detained as terrorists should be given rights (80\%) and afforded lawyers $(78 \%)$.

${ }^{14}$ Morton H. Halperin, "Less Secure, Less Free," The American Prospect vol. 12 no. 20, November 19, 2001 (Even the AG did not read the ATA.) and Beryl A. Howell, "Seven Weeks: The Making of the USA PATRIOT Act," 72 Geo. Wash. L. Rev. 1145 (2004). ${ }^{15}$ The Bush Administration has rejected this charge, emphatically. Viet Dinh "A White Paper: How Does the USA Patriot Act defends democracy." The Foundation for the Defense of Democracies, June 1, 2004. (During the drafting of the anti-terrorism measures, the Administration has listened to and took heed from a coalition of concerned voices. (p. 3) http://www.defenddemocracy.org/usr_doc/USA_Patriot_Act.pdf ${ }^{16}$ Beryl A. Howell, "Seven Weeks: The Making of the USA PATRIOT Act," 72 Geo. Wash. L. Rev. 1145 (2004). (AG Ashcroft repeatedly demanded passage of Administration proposals with no debate and revisions, with the threat of political fallout of yet another terrorism as the political weapon of choice.) See Author, "The Making of USA PATRIOT ACT: "Legislative Climate and Political Forces." (On file with author). ${ }^{17}$ The two exceptions being Beryl A. Howell, "Seven Weeks: The Making of the USA PATRIOT Act," 72 Geo. Wash. L. Rev. 1145 (2004). (Howell benefited from being an insider to the legislative process. He worked for Senator Leahy, then the Chairman of Senate Judiciary Committee) and Robert O' Harrow Jr. (with assistance from the Center for Investigative Reporting) "Six Weeks in Autumn," Washington Post. Sunday, October 27, 2002; Page W06 (The USA PATRIOT ACT was rushed through Congress by the administration under the stewardship of AG staff.) There was suggestion that the President was personally involved by giving the matching order, i.e. AG Ashcroft acted only as a loyal foot soldier.) 
This article, based on a larger research project, ${ }^{18}$ investigated into the legislative history of the USA PATRIOT ACT, broadly define. This article is a first of two part series reporting upon: "The Making of the USA PATRIOT ACT". It is subtitled: "Legislative Process and Dynamics". The article to follow is subtitled: "Legislative Climate and Political Context."19

This article examined the Congressional records, tracked the floor debates and examined newspaper records to understand the process and document the dynamics as to how the USA PATRIOT ACT was passed. The subsequent article would be looking into the historical context, political climate, social circumstances, and cultural milieu to ascertain why the USA PATRIOT ACT was made in the way and manner it did.

This article is organized into the following parts. After this "Introduction," Part II: "The Legislative Process" traced the origin and followed the development of the USA PATRIOT ACT. It observed that the ACT was rushed through the Congress with few consultations with the public, collectively, and virtually no participation by the legislators, individually. Part III: "A failure of process" investigated into how the legislative process had failed? It further observed that such a failure of process set the stage for and resulted in post legislative challenges to the USA PATRIOT ACT. Part IV: "A Preliminary Assessment" descried and discussed some of concerns raised and issued posed about the USA PATRIOT ACT. Part V: "Concluding observations" summarized the article's major findings as it discussed some of the reasons why the legislative process was compromised, a subject matter to be dealt with at length and in more detail in the second part to: "The Making of USA PATRIOT ACT."

${ }^{18}$ The article is the result of a three years research project $(2002-2005)$ entitled "The Impact and Implications of USA PATRIOT Act on American Society." Research output to-date include: "The Impact and Implications of USA PATRIOT Act: A Preliminary Analysis" (Midwest Criminal Justice Association Annual Conference, October 2-4, 2004); "USA PATRIOT Act: Just the Facts" ("Patriot Act Forum," League of Women Voters, Oshkosh, WI, Nov. 18, 2003); "The Impact and Implications of USA PATRIOT Act on American libraries" (Asian Association of Police Studies IV Annual Conference, Dec. 15-18, 2003) and "The Impact and Implications of USA PATRIOT Act on American Higher Education" (Academy of Criminal Justice Sciences Annual Conference, March 9-13, 2004). "The USA PATRIOT ACT: Some Unanswered Questions," Wisconsin Political Scientist Vol. IX (3), Fall 2003, pp. 6-9; "USA PATRIOT ACT: More Questions than Answers" (2005) and "Implementing the USA PATRIOT ACT: A Case Study of the Student and Exchange Visitor Information System (SEVIS)" (2005), both currently under publication review.

${ }^{19}$ Author, "The making of the USA PATRIOT ACT II: "Legislative Climate and Political Context." (October 1, 2005). Under review. On file with author. 


\section{II \\ The Legislative Process}

\section{Combating Terrorism Act of 2001 - AMENDMENT NO. 1562 20 \\ The first comprehensive and significant post 9/11 anti-terrorism measure ${ }^{21}$ introduced was in the form of an amendment attached to a budget appropriation bill "DEPARTMENTS OF COMMERCE, JUSTICE, AND STATE, THE JUDICIARY, AND RELATED AGENCIES APPROPRIATIONS ACT, 2002" (HR 2500) in the Senate on September}

\footnotetext{
${ }^{20}$ Combating Terrorism Act of 2001, S. Amdt. 1562, 107th Cong. (2001), http://www.cdt.org/security/010913senatewiretap2.shtml. (last visited November 16, 2003).

${ }^{21}$ For a list of 9/11 legislations, see "LEGISLATION RELATED TO THE ATTACK OF SEPTEMBER 11, 2001," http://thomas.loc.gov/home/terrorleg.htm The Acts and Bills introduced during the two week of 9/11 included: Victims of Terrorism Tax Relief Act of 2001, Public Law No: 107-134 (introduced 9/13/2001) (“Exempts from income taxes any individual who dies as a result of wounds or injury incurred from the terrorist attacks against the United States on April 19, 1995, or September 11, 2001, or who dies as a result of illness incurred from a terrorist attack involving anthrax occurring on or after September 11, 2001, and before January 1, 2002 (such attacks).”); Public Safety Officer Benefits Bill, Public Law No: 107-37 (introduced 9/13/2001) ("To provide for the expedited payment of certain benefits for a public safety officer who was killed or suffered a catastrophic injury as a direct and proximate result of a personal injury sustained in the line of duty in connection with the terrorist attacks of September 11, 2001.”); Intelligence Authorization Act for Fiscal Year 2002 ("To authorize appropriations for fiscal year 2002 for intelligence and intelligence-related activities of the United States Government, the Community Management Account, and the Central Intelligence Agency Retirement and Disability System, and for other purposes.”); 2001 Emergency Supplemental Appropriations Act for Recovery from and Response to Terrorist Attacks on the United States, Public Law No: 107-38 (introduced 9/14/2001) ("Making emergency supplemental appropriations for the fiscal year 2001 for additional disaster assistance, for anti-terrorism initiatives, and for assistance in the recovery from the tragedy that occurred on September 11, 2001, and for other purposes."); Air Transportation Safety and System Stabilization Act, Public Law No: 107-42 (introduced on $9 / 21 / 2001$ ) ("To preserve the continued viability of the United States air transportation system.”); Freedom Bonds Act of 2001, H.R.2899 (introduced 9/17/2001) (“To authorize the Secretary of the Treasury to issue Freedom Bonds in response to the September 11, 2001, hijackings and attacks on the Pentagon and the World Trade Center, and for other purposes."). For a summary of existing terrorism federal law provisions as of October 2001, see "Terrorism Legislation Comparison," http://www.netcaucus.org/books/surveillance2001/docs/EFF_Leg_Compare_Chart.pdf
} 
13, 2001, ${ }^{22}$ i.e. AMENDMENT NO. 1562, entitled: "Combating Terrorism Act of 2001." (CTA) ${ }^{23}$

The professed purpose CTA was: "To enhance the capability of the United States to deter, prevent, and thwart domestic and international acts of terrorism against United States nationals and interests. ${ }^{, 24}$ In more layman's term and as Senator Hatch put it: "It is essential that we give our law enforcement authorities every possible tool to search out and bring to justice those individuals who have brought such indiscriminate death into our backyard." 25

The CTA was cosponsored by Senators Hatch (R-Utah), Feinstein (D-CA), and Kyl (R-Arizona). Senators Dewine, Session, Thompson, Thurmond, McCain, and Schumer also joined. ${ }^{26}$ The CTA passed the Senate two days after 9/11, with about 30 minutes of floor debate and one lone dissenting voice, i.e. that of Sen. Patrick Leahy (D-VT). Leahy wanted more time to study the bill. ${ }^{27}$ This was an all too familiar pattern with post 9/11 legislative measures,${ }^{28}$ to be repeated with the USA PATRIOT ACT. ${ }^{29}$

\footnotetext{
${ }^{22}$ See Congressional Record, September 13, 2001, at pages S9401-4.

${ }^{23}$ For a discussion, see "Liberty for Security," Duke L. \& Tech. Rev. 0036 (2001), esp. "Combating Terrorism Act of 2001." For a copy of the CTA text, see http://msbnetworks.net/ hillct/cta/ For Senate floor debate, see "Senate debate on wiretap and anti-terrorism proposals," Sept. 13, 2001 (Hereinafter "Combating Terrorism Act of 2001 debate") http://www.cdt.org/security/010913senatewiretap.shtml

${ }^{24}$ See Combating Terrorism Act of 2001 debate.

25 Declan McCullagh, "Senate OKs FBI Net Spying," WIRED NEWS 12:55 PM Sep. 14, $2001 \mathrm{PT}$ http://www.wired.com/news/politics/0,1283,46852,00.html

${ }^{26}$ Senator Kyl, Hatch, and Feinstein were all members of the Subcommittee on Technology, Terrorism, and Government Information and Terrorism, (106 ${ }^{\text {th }}$ Congress), and later the Technology and Homeland Security $\left(107^{\text {th }}\right.$ and $108^{\text {th }}$ Congress $)$ which was responsible for "Oversight of anti-terrorism enforcement and policy". Senator Feinstein was the Chairman of Subcommittee on Technology, Terrorism, and Government Information (106 ${ }^{\text {th }}$ Congress) in 2001 with Senator Kye acting as the Ranking Republican. Senator Kyl was the Chairman and Senator Feinstein was the Ranking Democrat on the Terrorism, Technology and Homeland Security $\left(107^{\text {th }}\right.$ and $108^{\text {th }}$ Congress).

${ }^{27}$ See Senate Leahy floor speech, Combating Terrorism Act of 2001 debate.

${ }^{28}$ See Author, "The USA PATRIOT Act: Some Unanswered Questions" (September 1, 2005) (Under review, on file with author), esp. "Table 2: The number of 9/11 legislative actions acted upon within six (6) months," referencing Margaret F. Klemm \& Albert C. Ringelstein, "Congressional Response to the September 11, 2001 Terrorist Attacks," extensions. A Journal of Carl Albert Center (Fall 2002).
} 
The CTA was intended to provide law enforcement officials with the necessary resources and added legal authority to fight terrorism, particularly in the investigation of $9 / 11$ terrorists and to bring them to justice. As observed by Senator Hatch in introducing the CTA: "we, as lawmakers, must take every step possible to ensure, in addition to adequate financial resources, that the law enforcement community has the proper investigative tools at its disposal to track down the participants in this evil conspiracy and to bring them to justice." 30

Facing with a national crisis of yet untold proportion, the Congressional leadership had contingency plans to secure the nation, in the event CTA failed to materialize, there were to be back up plans. For example, on September 20, 2001, Rep. Lamar Smith circulated a bill - Public Safety and Cyber Security Enhancement Act (PSCSEA) - similar to the CTA as a backup for S.A. 1562 should H.R. 2500 failed to pass. Sen. Patrick Leahy was also working on his own anti-terrorism bill, later passed as the USA ACT.

The CTA was demanded by the public (to secure the nation) ${ }^{31}$ and required by the situation (in fighting an illusive enemy). ${ }^{32}$ Above all else it reflected and reinforced the nation's sober mood and crisis mentality. The political climate of the time was in seeking security at all costs. ${ }^{33}$ Most of the provisions have been recommended by former anti-terrorism commissions, e.g. National Commission on Terrorism ${ }^{34}$ and requested by law enforcement

\footnotetext{
${ }^{29} I d$.

${ }^{30}$ See Combating Terrorism Act of 2001 debate.

${ }^{31}$ Senator Kye: "But, as policymakers, we have also been asked some hard questions by our constituents and those questions include things such as: Why can't our Government do something about these horrible crimes?" Id.

32 "On the Importance of Anti-terrorism Legislation," ("Viet Dinh: I think the American people have made their preferences very clear in their public statements expressed to the various news agencies, not only with respect to the fight against terrorism, but on this package in particular.") http://www.aclj.org/news/nf_011004_viet_dinh_interview.asp 33 Author, "The making of the USA PATRIOT ACT II: The Legislative Climate and Political Context," (October 1, 2005). Under review. On file with author.

${ }^{33}$ Combating Terrorism Act of 2001, S. Amdt. 1562, 107th Cong. (2001).

${ }^{34}$ See testimony of Senator Kyle, Combating Terrorism Act of 2001 debate. ("We implement one of the recommendations of the Bremer commission, which said there is a lot of illicit fundraising for terrorist organizations going on in the United States. ")
} 
officials for years. As Senator Kye observed when speaking in support of the bill: "In addition to that, we have had a lot of testimony from the Director of the FBI and other U.S. Government officials all imploring us to do some things to help in this battle against terrorism." ${ }^{35}$ Nearly half of the provisions have passed the Senate one and half year before. ${ }^{36}$

The "Combating Terrorism Act of 2001" provided for improvement on:

(a) Readiness and readiness The Comptroller General was asked to report upon the capacity and readiness of National Guard in the event of a terrorist attack. Particularly, "an assessment of the capabilities of the National Guard to preemptively disrupt a terrorist attack within the United States involving weapons of mass destruction, and to respond to such an attack" (Section 812 (a). ${ }^{37}$

(b) Scientific and technology research The President was asked to establish a long-term and comprehensive scientific and technology research program to prevent, preempt, detect, interdict, and respond to catastrophic terrorist attacks (Section 813). ${ }^{38}$

(c) Legal authority The Attorney General was asked to conduct a review of the legal authority of the Federal government agencies to adequately respond to - prevent, preempt, detect, and interdict - "catastrophic terrorist attacks." $(\text { Section } 814)^{39}$

(d) Intelligence recruitment The Director of Central Intelligence was asked to rescind the 1995 CIA guidelines relating to "the recruitment of persons

Bremer and Sonnenberg, "Countering the Changing Threat on International Terrorism," National Commission on Terrorism. http://www.fas.org/irp/threat/commission.html ${ }^{35} \mathrm{Id}$.

${ }^{36}$ See testimony of Senator Kyle, Combating Terrorism Act of 2001 debate. ("In fact, we incorporated some of the provisions of these commission recommendations in the bill that passed the Senate a year and a half ago.")

${ }^{37}$ SEC. 812. ASSESSMENT OF NATIONAL GUARD CAPABILITIES TO PREEMPTIVE.

${ }^{38}$ SEC. 813. LONG-TERM RESEARCH AND DEVELOPMENT TO ADDRESS CATASTROPHIC TERRORIST ATTACKS.

${ }^{39}$ SEC. 814. REVIEW OF AUTHORITY OF FEDERAL AGENCIES TO ADDRESS CATASTROPHIC TERRORIST ATTACKS. 
who have access to intelligence related terrorist plans, intentions and capabilities." (Section 815)

(e) Wiretapping The President was asked to report on "legal authorities that govern the sharing of criminal wiretap information under applicable Federal laws, including section 104 of the National Security Act of 1947 (50 U.S.C. 403-4). (Section 816 (a). ${ }^{41}$

(f) Terrorism financing The Federal Government was asked to use all the tools available to prevent, deter, or disrupt the fundraising activities of international terrorist organizations, and it should do so. (Section 817 (b) ${ }^{42}$

(g) Controls of biological pathogens The Attorney General was asked to report upon on "the means of improving United States controls of biological pathogens and the equipment necessary to develop, produce, or deliver biological weapons" (Section 818 (a). ${ }^{43}$ Specifically, The Attorney General was asked to report upon measures to protect possession, handling, storing, or transporting of such pathogens from illegal theft or other wrongful diversion (Section 818 (b).

(i) Employee liability insurance The Head of Federal agencies were to reimburse law enforcement agents and intelligence employees for professional liability insurance when conducting counterterrorism duties (Section $819(a)^{44}$

(j) Use a pen register or trap and trace device Federal and State investigative or law enforcement officers are authorized to use a pen register or trap and trace device to obtain "dialing, routing, addressing" information by certifying "to the court that the information likely to be obtained by such installation and use is relevant to an ongoing criminal investigation."

\footnotetext{
${ }^{40}$ SEC. 815 . GUIDELINES ON RECRUITMENT OF TERRORIST INFORMANTS

${ }^{41}$ SEC. 816. DISCLOSURE BY LAW ENFORCEMENT AGENCIES OF CERTAIN INTELLIGENCE OBTAINED BY INTERCEPTION OF COMMUNICATIONS.

${ }^{42}$ SEC. 817. JOINT TASK FORCE ON TERRORIST FUNDR

${ }^{43}$ SEC. 818. IMPROVEMENT OF CONTROLS ON PATHOGENS AND EQUIPMENT FOR PRODUCTION OF BIOLOGICAL WEAPONS

${ }^{44}$ SEC. 819. REIMBURSEMENT OF PERSONNEL PERFORMING COUNTERTERRORISM DUTIES FOR PROFESSIONAL LIABILITY INSURANCE
} 
(Section.832 (b). ${ }^{45}$ It also authorized the emergency installation of such devices by U.S. Attorneys if there is immediate threat to "national security", public health or safety", "attack on the integrity or availability of a protected computer (Section.832 (c)

(k) Intercept wire, oral and electronic communications Law enforcement officials can intercept wire, oral and electronic communications in the investigation of terrorism (Section 833$)^{46}$ and computer fraud and abuse (Section 834) offenses. ${ }^{47}$

As it turned out, the process and debate over AMENDMENT NO. 1562 served as a dry run for the USA PATRIOT ACT; acting as harbinger of things to come. Specifically, it anticipated many of the substantive issues raised, e.g. roving wiretap as threatening civil liberties, and rehearsed most of process related arguments made, e.g. Congress should not rush to judgment without proper notice and public hearing. For example, much like the USA PATRIOT Act the CTA was supplied to the Senators only 30 minutes before the floor debate. ${ }^{48}$ In this regard, Senator Leahy CTA floor speech was instructive on things to come:

"Unfortunately, because this is something that we have had no hearings on, we haven't had the discussions in the appropriate committees--Intelligence, Armed Services, and Judiciary--we are somewhat limited in opposition... I would feel far more comfortable voting on something like this if these various committees not only had a chance to look at it but that President Bush's administration--the Attorney General, the Director of CIA, the Secretary of Defense--would have the opportunity to let us know their views on it. I would feel far more comfortable with that." 49

${ }^{45}$ SEC. 832. MODIFICATION OF AUTHORITIES RELATING TO USE OF PEN REGISTERS AND TRAP AND TRACE DEVICES.

${ }^{46}$ SEC. 833. AUTHORITY TO INTERCEPT WIRE, ORAL, AND ELECTRONIC COMMUNICATIONS RELATING TO TERRORISM OFFENSES.

${ }^{47}$ SEC. 834. AUTHORITY TO INTERCEPT WIRE, ORAL, AND ELECTRONIC COMMUNICATIONS RELATING TO COMPUTER FRAUD AND ABUSE.

${ }^{48}$ Morgan Streetman, "Liberty for Security," 2001 The Duke Law \& Technology Review (DLTR) 0036, para. 8 http://www.law.duke.edu/journals/dltr/articles/2001dltr0036.html

${ }^{49}$ See Combating Terrorism Act of 2001 debate. 
The CTA did not attract much immediate media report or public attention. ${ }^{50}$ The nation was still taken back over the aftermath and dealing with the consequences of the $9 / 11$ attack.

There were however serious concerns and vocal complaints over the vagueness of many of its provisions, e.g. the exact meaning of "addressing" and "routing" data accessible by pen register and track and trace order, ${ }^{51}$ and their erosive impact on liberties, e.g. how intrusive is electronic surveillance on web based activities, ${ }^{52}$ form some quarters, mainly from long established interest (human rights) groups, such as ACLU, and (civil rights) advocacy

\footnotetext{
${ }^{50}$ There were occasional constituent letters to the law-makers. There was not systematic counting or analysis of such letters. See letter of Mike Perry (505 E. White St \#4, Champaign, Il, 61820)to Dear Senators Durbin and Fitzgerald, and Representative Johnson (A-G Ashcroft's Anti-Terrorism Act (ATA); Sen. Leahy's Uniting and Strengthening of America Act (USAA); Rep. Smith's Public Safety and Cyber Security Enhancement Act (PSCSEA, H.R. 2915); Sen. Hatch's Combating Terrorism Act (CTA, amendment S.A. 1562 to bill H.R. 2500); and Sen. Graham's Intelligence to Prevent Terrorism Act (IPTA, S. 1448), and Sen. Gregg's draft anti-encryption legislation were ill advised. Instead of catching hard core terrorists, they would affect innocent citizens. For example by declaring computer crime terrorism acts, it end up serving extensive punishments for "young, curious programmers, essentially pranksters" who one day might "grow up to be accomplished security professionals.") http://fscked.org/rants/letters/Repletter

51،'Senate OKs FBI Net Spying," Wired, September 11, 2001 ("Nobody really knows what routing and addressing information is.... If you're putting in addressing information and routing information, you may not just get (From: lines of e-mail messages), you might also get content," the source said. ) http://www.wired.com/news/politics/0,1283,46852,00.html

52 See open web e-mail to Senator Feinstein "14-09-2001: Combating Terrorism Act of 2001," http://www.kocharhook.com/nick/letters/cta2001.html
} 
coalitions, such as Electronic Frontier Foundation. ${ }^{53}$ For example, the Electronic Frontier Foundation was critical of various aspects of CTA: ${ }^{54}$

(1) CTA expands "traditional" wiretap authority beyond recognition. Before CTA, wiretap orders were authorized based on a short list of well defined predicated offences. Now, the CTA allows for wiretapping based on loosely copulated terrorism crime (Section 833$)^{55}$ and computer fraud and abuse (Section 834). ${ }^{56}$

(2) CTA allows for application of "pen register" and "track and trace" to electronic communication, e.g. e-mail, web surf, URL search. This opens up the possibility of tracking content.

The CTA expands the pen register concept from merely capturing phone numbers ${ }^{57}$ to capturing routing and addressing information in any electronic communications, e.g. Internet communications. Thus the definition of pen register under the amended (18 U.S.C. § 3127(3) now reads: "a device or process which records or decodes dialing, routing, addressing, or signaling information transmitted by an instrument or facility from which a wire or electronic communication is transmitted ..." Similarly, 18 U.S.C. § 3127(4) defines "trap and trace device" means a device or process which captures the

53 The Electronic Frontier helps keep track of impact of anti-terrorism measures (not all of them related to terrorism law or USA PATRIOT ACT) from day one: "Chilling Effects of Anti-Terrorism "National Security" Toll on Freedom of Expression, including: Websites Shut Down by US Government; Websites Shut Down by Other Governments; Websites Shut Down by Internet Service Provider; Websites Shut Down or Partially Removed by Website Owner; US Government Websites That Shut Down or Removed Information; US Government Requests to Remove Information Media Professionals Terminated or Suspended; Other Employees Terminated or Suspended; Related Incidents. http://www.eff.org/Censorship/Terrorism_militias/antiterrorism_chill.php\#websiteshutdo wnusgov

${ }^{54}$ EFF Analysis of SA 1562, Subtitle B (Sept. 19, 2001), http://www.eff.org/ (last visited October 2, 2001).

${ }^{55}$ SEC. 833. AUTHORITY TO INTERCEPT WIRE, ORAL, AND ELECTRONIC COMMUNICATIONS RELATING TO TERRORISM OFFENSES.

${ }^{56}$ SEC. 834. AUTHORITY TO INTERCEPT WIRE, ORAL, AND ELECTRONIC COMMUNICATIONS RELATING TO COMPUTER FRAUD AND ABUSE.

${ }^{57}$ Under the former law "pen register" and "track and trace" devices only applied to "wire" communications. Thus, a "pen register" is "a device which records or decodes electronic or other impulses which identify the numbers dialed or otherwise transmitted on the telephone line to which such device is attached ..." 
incoming electronic or other impulses which identify the originating number or other dialing, routing, addressing, and signaling information reasonably likely to identify the source of a wire or electronic communication, provided, however, that such information shall not include the contents of any communication.."

(3) CTA allows for multi-jurisdiction "pen register" and "trap and trace" orders. Whereas before CTA pen register and trap and trace orders only apply "within the jurisdiction of the court." The CTA allows for one stop "pen register" and "trap and trace" orders that are applicable nation wide, without the legal jurisdiction and beyond the effective supervision of the authoring judge: "The order shall, upon service of the order, apply to any entity providing wire or electronic communication service in the United States whose assistance is required to effectuate the order." (Section 832 (b) (1).

(4) CTA lowers the threshold of approval (i.e. relevant to ongoing criminal investigation) and minimizes judicial supervision (i.e. court order based on certification of law enforcement officials) in the application for "pen register" and "trap and trace" orders in electronic surveillance cases. In so doing, CTA extends the old wiretap order application standard and procedures to electronic searches. ${ }^{58}$ Section 832 (b) (1) reads in pertinent part: "Upon an application made under section 3122(a)(1) of this title, the court shall enter an ex parte order authorizing the installation and use of a pen register or trap and trace device if the court finds that the attorney for the Government has certified to the court that the information likely to be obtained by such installation and use is relevant to an ongoing criminal investigation." (Emphasis supplied)

There were also concerns with the legislative process:

"Perhaps extending the privileges of government to limit our privacy is something that should be done in half an hour in the middle of the night, as it was here, but then again, maybe

\footnotetext{
5818 U.S.C. 3223 provides in pertinent parts "the court shall enter an ex parte order authorizing the installation and use of a pen register or a trap and trace device within the jurisdiction of the court if the court finds that the attorney for the Government or the State law enforcement or investigative officer has certified to the court that the information likely to be obtained by such installation and use is relevant to an ongoing criminal investigation."
} 
Senators Carl Levin of Michigan and Patrick Leahy of Vermont were correct, that this was all being done far too quickly, with a speed in fact that prevented most of the senators to make a full review of the legislation which was presented to them a mere half hour before they were to vote on it."

Some felt that the CTA were more show than substance, ${ }^{60}$ symbolic than real. $^{61}$

The Bush administration in general, and AG Ashcroft in particular, has been consistently blamed and universally condemned by many in the United States for using 9/11 to push for draconian measures, transforming United States into an Owellian state with the passage of CTA - MATA - ATA Patriot Act. ${ }^{62}$ As lamented by Al Gore: "They have taken us much farther down the road toward an intrusive, 'big brother'-style government - toward the dangers prophesied by George Orwell in his book '1984' - than anyone ever thought would be possible in the United States of America." ${ }^{63}$

While it certainly is true that Ashcroft was responsible with originating and implementing many of the post 9/11 terrorism counter-measures, he did not drafted all of them out of clean cloth. A fair reading of historical records suggests that many of the counter-measures already existed on the book and

59 "Combating Terrorism Act of 2001 - Analyzed (Op-Ed),"Tue Sep 18th, 2001 at 12:24:17 PM EST http://www.kuro5hin.org/story/2001/9/17/22230/2697

${ }^{60}$ Bon Barr the maverick Republican Representative openly questioned the necessity and utility of the CTA. "Fighting Terrorism, Preserving Civil Liberties," CATO, POLICY FORUM, Tuesday, October 2, 200. 4:00 p.m. (Featuring Rep. Bob Barr (R - Ga.), with commentary by Solveig Singleton, Senior Analyst, Competitive Enterprise Institute; Stuart Taylor, Senior Writer, National Journal; Jonathan Turley, Professor of Law, George Washington University.)

61 "SECRECY NEWS: from the FAS Project on Government Secrecy," September 14, 2001 (Most of legislation consisted of declaration of sense of Congress and requests for reports, rather than providing for new powers to fight terrorism. The exception being doing away with 1995 CIA guidelines governing the recruitment of informants who have committed human rights violations.) http://www.fas.org/sgp/news/secrecy/2001/09/091401.html 62 “Gore: Bush Has Failed to Make U.S. Safer," Earthlink, November 10, 2003. ${ }^{63} I d$. 
otherwise they were introduced by the Congress, as with making "pen register" and "track and trace" applicable electronically and nationally. ${ }^{64}$

\section{The MATA \& ATA}

The conceptualization of what eventually comes to be known as the USA PATRIOT ACT started with a simple instruction from President Bush ${ }^{65}$ to the Attorney General (AG) Ashcroft immediately after the 9/11 attack: "John, make sure this (9/11 - terrorism) can't happen again." "66 The AG took the charge seriously, and zealously, and above all else personally. ${ }^{67} 68$

${ }^{64}$ See "An Analysis of How the Events of September 11 May Change Federal Law," Tech Law Journal, September 17, 2001

${ }^{65}$ To date, there is no investigation into the role of President Bush in the drafting and passage of the USA PATRIOT ACT and related anti-terrorist, measures. Was President Bush a hands-off manager, aloof and detached, as many observers made him out to be? To what extent and in what manner did Bush contributed - in content and process - to the passage of the USA PATRIOT ACT? 9/11 was a defining moment to the Bush administration. How Bush handled 9/11, from talking to the crowd at ground zero to pushing the USA PATRIOT ACT through Congress, unmistakably reflected Bush governance philosophy and management style. These are some of the traits attributed to Bush: ideological, elitists, not curious, not intellectual, focused, single minded, stubborn. commanding not consulting. not given to compromise, contempt for Congress, dismissive of the media.

${ }^{66}$ The instruction was given in the White House in the afternoon of 9/11. Steven Brill, After: How American Confronted the September 12 Era (N.Y.: Simon \& Shuster, 2003), p. 15.

67 Attorney General Ashcroft Announces the Formation of Anti-terrorism Task Forces in U.S. Attorney Offices, DOJ, Press release, September 18, 2001; Letter to Mayors from Attorney General Ashcroft (9/19/01) (on formation of anti-terrorism task force) (September 19, 2001); ATTORNEY GENERAL ASHCROFT DIRECTS LAW ENFORCEMENT OFFICIALS TO IMPLEMENT NEW ANTI-TERRORISM ACT, DOJ, Press release, FRIDAY, OCTOBER 26, 2001; Dan Eggen, “Ashcroft champions Patriot Act Responding to critics, attorney general says law is linchpin of war on terrorism," San Francisco Chronicle, Wednesday, August 20, 2003 (The AG took personally charge of a national campaign (18 cities) to drum up support form the USA PATRIOT ACT). For an assessment of Ashcroft's tenure as AG and his impact on war on terrorism, see "CONTROVERSIAL TENURE" PBS- Online News-hour November 11, 2004. http://www.pbs.org/newshour/bb/law/july-dec04/ashcroft_11-11.html

${ }^{68}$ In public service, officials are supposed to separate private preferences from public goods. Public policy choices are determined by how such choices reflect public values and promote public interests, not personal ones. In the case of Ashcroft, he not only failed to draw the distinction but actively make his own ideology, value and interests stands for the good of the nation; from religious believes, to moral values to political ideology. JUDY BACHRACH, "John Ashcroft's Patriot Games," Vanity Fair Feb. 1, 2004. http://www.mindfully.org/Reform/2004/Ashcroft-Patriot-Games1feb04.htm 
The AG turned to Viet Dinh, ${ }^{69}$ an Assistant Attorney General in charge of Department of Justice, ${ }^{70}$ Office of Legal Policy, to work on an anti-terrorism package on the same day. ${ }^{71}$ On Thursday (September 13, 2001) Dinh told Ashcroft that the package - Mobilization Anti-Terrorism Act (MATA) ${ }^{72}$ -

("'There are only two things you find in the middle of the road, a moderate and a dead skunk" He believes that "you can legislate morality," and that any senator who suggests otherwise will simply be legislating "immorality, and we've done too much of that already." The attorney general invested his fight for the Patriot Act with a Crusader's fervor, "questioning his opponents' patriotism...")

${ }^{69}$ Viet Dinh was know as the "chief architect of the USA Patriot Act. "At Home in War on Terror: Viet Dinh has gone from academe to play a key behind-the scenes role. Conservatives love him; others find his views constitutionally suspect." Los Angeles Times September 18, 2002. http://www.asianam.org/viet\%20dinh.htm In time, he becomes the ACTS chief spokesman and defender. His rational for the USA PATRIOT $\mathrm{ACT}$ is always couched in terms of security before freedom; one cannot enjoy the later without the guarantee of the former. Viet Dinh "A White Paper: How Does the USA Patriot Act defends democracy." The Foundation for the Defense of Democracies, June $1,2004$.

70 OPIC: USA Patriot Act; INTERVIEW SUBJECT: Viet Dinh; FILM: THE COST OF FREEDOM - Civil Liberties, Security and the USA PATRIOT Act; INTERVIEWER: Alison Rostankowski/Chip Duncan; TRANSCRIPTS: Troy Avdek. (C) 2004 The Duncan Group, Inc. http://www.duncanentertainment.com/interview_vietdinh.php (Viet Dinh Interview)

${ }^{71}$ Another account suggested that Dinh's marching order came on September 12, 2001 (Wednesday) indirectly by way of Adam Ciongoli, Ashcroft's counselor. Robert O'Harrow Jr., "Six Weeks in Autumn," Washington Post Sunday, October 27, 2002; Page W06.

${ }^{72}$ The original draft of the anti-terrorism package worked on by Dinh and released to the Congress on September 19, 2001 was a 31 page document entitled MATA. For the proposed text of the first draft of MATA, see http://www.eff.org/Privacy/Surveillance/20010919 mata_bill_draft.html For a fair and balance analysis of original draft to MATA, see DOJ http://www.eff.org/Privacy/Surveillance/20010919 doj mata analysis.html

The second draft of the MATA, a 21 pages bill, rendered on September 19, 20011- 12.30 $\mathrm{pm}$, is entitled ATA of 2001. For text of second draft of MATA a/k/a ATA, see http://www.cdt.org/security/010920bill text.pdf

For DOJ analysis of second draft of MATA, i.e. ATA, see http://www.cdt.org/security/010919terror.pdf Draft 9/19 12:30 pm [ET] Since then MATA and ATA has been interchangeably used to refer to both drafts. As late as September 24, 2001, the AG still referred to the second draft MATA, when people outside the administration have correctly identity it as ATA. See "ATTORNEY GENERAL ASHCROFT OUTLINES MOBILIZATION AGAINST TERRORISM ACT," USDOJ September 24, 2001. http://www.usdoj.gov/opa/pr/2001/September/492ag.htm 
would be ready by Friday (September 14, 2001). ${ }^{73}$ Dinh was assisted by David Carp, a DOJ lawyer who helped drafted the Oklahoma City (1995) anti-terrorism measures, ${ }^{74}$ with input for John Yoo $^{75}$ who later co-authored a repot finding that Geneva Conventions do not apply to Taliban or Al Qaeda fighters as a matter of international law because Afghanistan was a "failed state". ${ }^{76}$

In the course of business and little over six weeks a $20-30$ pages of MATA - ATA turned into a document which was 131 pages in length with 1016 different sections.

According to Dinh his first order of business was to consult law enforcement agents and prosecutors all over the nation for their ideas on how best to fight terrorism, in the short term and over the long haul. ${ }^{77}$ The three criteria for

${ }^{73}$ Steven Brill, After: How American Confronted the September 12 Era (N.Y.: Simon \& Shuster, 2003), p. 52.

${ }^{74}$ Steven Brill, After: How American Confronted the September 12 Era (N.Y.: Simon \& Shuster, 2003), p. 53.

${ }^{75}$ It is of interest to note that two Asian-Americans were appointed to leadership position in leading the legal charge on war on terror, domestically (Dinh) and internationally (Yoo). Was this a case of co-incidence? (Asian-Americas, especially in public law, are not in abundance inside and outside the Administration.) Was this a case of ideological compatibility, i.e. Asian Americans are more conservative minded when it comes to defense issues? (Dinh was a member of the Federalist Society.) Was this a case of strategic deployment, i.e. to make it appears that war on terror is not one of white vs. colored. Was this a case of meritorious appointment, i.e. Asian Americans in general and Dinh and Yoo in particular were distinguished legal professionals of their own right. Both of them came from ranked law schools. Both of them ended up as law professors. Was this a case of Bush (affirmative action) policy at work, e.g. Bush has a track record of appointing high profile government jobs to minorities - Powel and Rice at State and Gonzalez at Justice. The investigation of the role played by Asian American in war on terror should be revealing of Bush's administration management philosophy and style, in turn shed light on the USA PATRIOT ACT's passage.

76 "Application of Treaties and Laws to Al Qaeda and Taliban Detainees" (Jan. 9. 2002) (with Robert J. Delahunty). See "THE BUSH ADMINISTRATION TORTURE MEMO SCANDAL," http://texscience.org/reform/torture/

${ }^{77}$ This consultation process (if substantiated) contradicted the common impression and repeated allegations that the Bush administration have no done enough to incorporate different ideas and opposing views in the drafting process. Alternative, the USA PATRIOT ACT was an ideological statement, not a consultative or consultation document. A question still remains, why was the ATA - MATA - USA PATRIOT ACT not distributed for comments through the proper channels, i.e. through OMB onto each and every related and affected agencies. 
suggestions from the field were: operationally necessity, limited impact on civil liberties, and conformity with Constitutionality. All told, fifty of the legislative proposals were compiled and submitted, most of them have been proposed and considered before, in one form or another. ${ }^{78}$ In fact, many of the proposed provisions in the MATA of 2001 were in fact off the shelf items from the 1996 anti-terrorism legislation, including roving wiretaps, releasing of customers' information from telephone and Internet companies, and seizing of personal property. ${ }^{79}$ Additional provisions of the proposed MATA included measures which: made it possible for law enforcement officials to obtain e-mail message header information and gather web browsing patterns without a wiretap order, ${ }^{80}$ dilute judicial supervision and control over roving wiretaps $;{ }^{81}$ permit law enforcement to share wiretap information with the Executive branch $;{ }^{82}$ reduce restrictions on Foreign Intelligence Surveillance Act (FISA) allowing it to be used domestically; ${ }^{83}$ allow grand jury evidence to be shared with the US intelligence community $;{ }^{84}$ permit the President to designate any "foreign-directed individual, group, or entity," including any United States citizen or organization as fitting for FISA surveillance, ${ }^{85}$ preventing people from exercising their first amendment rights in discussion terrorism related matters $;{ }^{86}$ establish a DNA database for every criminals and certain sex offenders unrelated to terrorism. ${ }^{87}$

Meantime, the first attempt to organize different opposition interest groups into a viable political force started to take shape, and has since been a thorn

\footnotetext{
78 This detracted from opponents' argument that the USA PATRIOT ACT provisions needed to be thoroughly researched and critically examined. See Viet Dinh Inerview. 79 There was an inconsistency in positions offered by the opponents to the Act, i.e. the USA PATRIOT ACT contained new and invasive provisions vs. USA PATRIOT ACT contained old and contested provisions. Jennifer Van Bergen, "The USA PATRIOT Act Was Planned Before 9/11," Truthout.org, 20 May, 2002 ("Many people do not know that the USA PATRIOT Act was already written and ready to go long before September 11th.") http://www.truthout.org/docs 02/05.21B.jvb.usapa.911.htm

${ }^{80}$ SEC. 103. MODIFICATION OF AUTHORITIES RELATING TO USE OF PEN REGISTERS AND TRAP AND TRACE DEVICES (2) (A) and 3 (B).

${ }^{81}$ SEC. 106. MULTI-POINT WIRETAPS.

${ }^{82}$.SEC. 108. AUTHORIZED DISCLOSURE.

${ }^{83}$ SEC. 157. PEN REGISTER AND TRAP AND TRACE AUTHORITY.

${ }^{84}$ SEC. 154 . FOREIGN INTELLIGENCE INFORMATION SHARING.

${ }^{85}$ SEC. 156 , DEFINITION.

${ }^{86}$ SEC. 202. DEFINITIONS RELATING TO TERRORISM

${ }^{87}$ SEC. 356. DNA IDENTIFICATION OF TERRORISTS
} 
to the administration effort in ushering a garrison state. The impetus and agenda for the organization effort was bested summed up by Net Hentoff, a longtime activities of civil rights causes and key members to the group:

To save our liberties, we have to organize nationally - as was done effectively in the civil rights and antiwar campaigns of the 1960s. There are already a large number of groups that can and should form an organizing and educational network to put ads in newspapers and on radio and television, set up teach-ins on campuses and in town meetings around the country, and plan a March on Washington on the order of the 1963 assembly addressed by Martin Luther King ("I Have a Dream").

On September 14, 2001 (Thursday), Halperin and ACLU called a meeting of interested parties and concerned groups at the ACLU white townhouse in D.C. to discuss strategy as to how to deal with anticipated legislative and administration clamp down on civil liberties in the name of national security. The meeting was precipitated by the rush of 9/11 legislations having the effect of eroding established Constitutional rights. The meeting was well attended by different interest groups. These groups came from across the political spectrum as representing different ideologies, interests and agenda; converging in opposing the government's civil rights depriving antiterrorism drive. For example, People for the American Way was formed in the 1981 to fight the insidious influence of the extreme right such as rightwing televangelists, including Jerry Falwell, Pat Robertson and Jimmy Swaggart. In joining the coalition, it was most concerned with compromising of civil rights and minorities rights. ${ }^{89}$ Project on Government Accountability (George Mason University) formed to improve government policy and decision making by promoting open policy choice and informed decisions through cost-benefit analysis. In joining the coalition, it sought to promote government accountability through a more open process. ${ }^{90}$ The Free Congress Foundation are political and moral conservatives dedicated to preserving traditional American way of life, e.g.

\footnotetext{
${ }^{88}$ Nat Hentoff, “Getting Back Our Rights Don't Brood and Despair. Organize!" Village Voce, December 7th, 2001 2:45 PM http://www.villagevoice.com/news/0150,hentoff,30634,6.html 89 "Statement of People for the American Way President G Ralph Neas." September 20, 2001. http://www.indefenseoffreedom.org/statements/pfaw release.pdf

90 "Whistle Blowers are Modern Paul Reveres Against Terrorism," September 20, 2001 http://www.indefenseoffreedom.org/statements/gap_release.pdf
} 
Judeo-Christian Western culture. As such it is against expansion of Federal power at the expense of the state and encroachment of individual rights by the government. ${ }^{91}$ Finally, "The Competitive Enterprise Institute is a nonprofit public policy organization dedicated to advancing the principles of free enterprise and limited government." In joining the coalition, it sought to reduce government regulation of business and restriction of free market in the name or as a result of war on terrorism. ${ }^{92}$

The coalition decided to issue a 10 points public statement calling for more rational debate:

\section{IN DEFENSE OF FREEDOM ${ }^{93}$}

1. On September 11, 2001 thousands of people lost their lives in a brutal assault on the American people and the American form of government. We mourn the loss of these innocent lives and insist that those who perpetrated these acts be held accountable.

2. This tragedy requires all Americans to examine carefully the steps our country may now take to reduce the risk of future terrorist attacks.

3. We need to consider proposals calmly and deliberately with a determination not to erode the liberties and freedoms that are at the core of the American way of life.

4. We need to ensure that actions by our government uphold the principles of a democratic society, accountable government and international law, and that all decisions are taken in a manner consistent with the Constitution.

5. We can, as we have in the past, in times of war and of peace, reconcile the requirements of security with the demands of liberty.

6. We should resist the temptation to enact proposals in the mistaken belief that anything that may be called anti-terrorist will necessarily provide greater security.

7. We should resist efforts to target people because of their race, religion, ethnic background or appearance, including immigrants in general, Arab Americans and Muslims.

91 . "Free Congress: Established Online Petition" September 20, 2001http://www.indefenseoffreedom.org/statements/freecongress release.pdf

$92 \mathrm{http://www.cei.org/pages/about.cfm}$

93 The statements in text is a verbatim account from http://www.indefenseoffreedom.org/ 
8. We affirm the right of peaceful dissent, protected by the First Amendment, now, when it is most at risk.

9. We should applaud our political leaders in the days ahead who have the courage to say that our freedoms should not be limited.

10. We must have faith in our democratic system and our Constitution, and in our ability to protect at the same time both the freedom and the security of all Americans.

The "In Defense of Freedom statement" was endorsed by more than 150 organizations, ${ }^{94} 300$ law professors, and 40 computer scientists. ${ }^{95}$

On a Sunday, September 16, 2001, AG John Ashcroft made public his intention to ask Congress to write tougher anti-terrorist laws and authorized more powers to fight terrorism. Subsequently on Monday, September 17, 2001, Ashcroft discussed the details of anti-terrorist package he intended to send to the Congress:

"Yesterday I met with several members of the House and Senate leadership, including the leadership of the Intelligence and Judiciary Committees. FBI Director Mueller and I discussed with them the current threat assessment, including our believe that associates of the hijackers that have ties to terrorist organizations may be a continuing presence in the United States. This threat assessment has helped us to identify several areas where we should strengthen our laws to increase the ability of the Department of Justice and its component agencies to identify, prevent and punish terrorism ...In the next few days, we intend to finalize a package of legislative measures that will be comprehensive. Areas covered include

\footnotetext{
${ }^{94}$ Other groups included NAACP Board of Directors; National Association of Criminal Defense Lawyers; National Council of Churches of Christ, National Council of La Raza, National Gay and Lesbian Task Force, National Lawyers Guild, National Native American Bar Association, NOW Legal Defense and Education Fund, Physicians for Human Rights, Rutherford Institute; the American-Arab Anti-Discrimination Committee; American Federation of State, County, and Municipal Employees; Amnesty International USA; Baptist Joint Committee on Public Affairs; Center for Constitutional Rights; Free Congress Foundation; Gun Owners of America; Leadership Conference on Civil Rights. ${ }^{95}$ http://www.indefenseoffreedom.org/
} 
criminal justice, immigration, intelligence gathering and financial infrastructure..."${ }^{96}$

The proposed anti-terrorists legislation promised to substantially enhance intelligence gathering capacity of law enforcement officials, including:

First, allowing wiretapping of person, instead on just phone number:

"And given the nature and availability of literally disposable telephones in modern society, we need to be able to have the court authority to monitor, not the phone, but the telephone communications of a person. .97

Second, allowing for nationally valid wiretapping order ("roving"): "so that one wiretap approval can be obtained for all jurisdictions working on an investigation, particularly given the mobility of individuals and the capacity of individuals who are mobile to communicate."${ }^{98}$

Third, making sure that terrorism offenses received the same amount of attention and priority as other serious crimes in terms of statute of limitations and penalty.

"For example, we are identifying instances where the law currently makes it easier to prosecute drug trafficking and organized crime or espionage than it is to prosecute terrorism...A person who harbors a person involved in espionage is subject to stiffer penalties than a person who harbors an individual involved in terrorism. We think this reflects an inadequate response to the kind of threat that terrorism poses to our culture." ${ }^{99}$

\footnotetext{
${ }^{96}$ Attorney General John Ashcroft Remarks, Press Briefing with FBI Director Robert Mueller, FBI headquarters, September 17, 2001.

http://www.yale.edu/lawweb/avalon/sept 11/doj brief002.htm

${ }^{97} \mathrm{Id}$.

${ }^{98} \mathrm{Id}$.

${ }^{99} \mathrm{Id}$.
} 
Finally, the proposed legislation make: "providing material support or resources to a terrorist organization an offense that would enable us to prosecute someone under the money laundering statutes."

On September 19, 2001 congressional members, White House and justice department leadership gathered formally to exchange proposals and informally to negotiate for compromise. AG John Ashcroft distributed the proposed MATA to members of Congress after Monday's press conference. ${ }^{101}$ The AG further "demanded" the MATA to be passed within the week, i.e. two days, ${ }^{102}$ with a dire warning issued on September 24, 2001 at a Congressional hearing:

"Everyday that passes with outdated statutes and the old rules of engagement, each day that so passes is a day that terrorists have a competitive advantage. Until Congress makes these changes we are fighting an unnecessary uphill battle." 103

While the MATA was not well received on the Hill, ${ }^{104}$ the Congress nevertheless promised expedited action. House Judiciary Committee

${ }^{100} \mathrm{http} / / / \mathrm{www}$.patriotresource.com/wtc/federal/0917/AGFBI.html

101 "DOJ's Anti-Terrorism Law Would Dismantle Civil Liberties, Legislate to Improve Security Not Eliminate Freedoms," Electronic Frontier Foundation Media Release, September 19, 2001. http://peacenowar.net/Sep\%2019\%2001--EFF.htm ${ }^{102} \mathrm{http}: / /$ www.patriotresource.com/wtc/federal/0917/AGFBI.html

${ }^{103}$ Such strong language, while reflecting a sense of frustration and urgency in the face crisis, is most unhelpful in promoting cooperation and facilitating coordinating action. “ASHCROFT ASKS CONGRESS FOR ANTI-TERRORISM MEASURES," PBS September 24, 2001, 5:45pm EST

${ }^{104}$ Brandon Spun, "Attorney General John Ashcroft Fails to Justify Encroachment of Civil Liberties," Insight Magazine, 9/25/01 (In spite of the AG plead for expedited action on MATA - "The American people do not have the luxury of unlimited time in erecting the necessary defenses to future terrorism attacks" - the law makers were more reticent, preferring a more wait and see approach. The immigrant provisions in Part II were found to be most objectionable. "Reps. Steve Chabot (R-Ohio), John Conyers (D-Mich.) and Zoe Lofgren (D-Calif.) shared their concern that such stipulations may allow for the indefinite and discriminatory detainment of aliens...Rep. Jerrold Nadler (D-N.Y.) was unwilling to give an attorney general "carte blanche" in deciding whether an already detained alien posed a threat to national security and how long the detainment of such an individual, if determined dangerous, could last". While Rep. Barney Frank (D-Mass.) was concerned "inappropriate release of information", Judiciary Committee members Reps. Maxine Waters (D-Calif.) and Bob Barr (R-Ga.) wanted more time to study the document.) 
Chairman F. James Sensenbrenner, Jr. (R-Wis.) issued a statement immediately upon receipt of the MATA:

"intend to have the House Judiciary Committee hold a legislative hearing followed by a full committee markup as soon as possible once legislation is introduced. This fair and deliberate schedule will allow for a full debate as well as expedited consideration by the full House."105

In the face of MATA, EFF Executive Director Shari Steele raised the recurring concern with emergency legislations and framed the ensuring debate to follow as one of liberty vs. security: "While it is obviously of vital national importance to respond effectively to terrorism, this bill recalls the McCarthy era in the power it would give the government to scrutinize the private lives of American citizens."

The EFF immediate issued a public statement, the first of many salvos, against the MATA:

"One particularly egregious section of the DOJ's analysis of its proposed legislation says that "United States prosecutors may use against American citizens information collected by a foreign government even if the collection would have violated the Fourth Amendment." 106

EFF Senior Staff Attorney Lee Tien followed with the observation that lesser liberty might not give us more security: "Operating from abroad, foreign governments will do the dirty work of spying on the communications of Americans worldwide. US protections against unreasonable search and seizure won't matter." 107

${ }^{105}$ Sensenbrenner Statement on Bush Administration's Anti-terrorism "Working Draft" Legislation," U.S. House of Representatives Committee on the Judiciary, F. James Sensenbrenner, Jr., Chairman. September 19, 2001. http://www.house.gov/judiciary/news091901.htm ${ }^{106} \mathrm{Id}$.

107 “DOJ's Anti-Terrorism Law Would Dismantle Civil Liberties," Electronic Frontier Foundation http://www.eff.org/ For Immediate Release: September 19, 2001 
The EFF further called upon its member to protest against he impending anti-terrorism laws, starting with a nation wide write in campaign. ${ }^{108}$

Originally, AG Ashcroft with the assistance of Rep. James Sensenbrenner (R-WI), Chairman of the House Judiciary Committee, was counting on a speedy passage of this legislation. Rep. Sensenbrenner planned to hold hearings on Monday (9/24), conduct a mark up session on Tuesday (9/25), and then take the bill to the House floor for final passage before the House breaks for the Yom Kippur holiday on Thursday (9/27). However, at the Committee hearing on Monday afternoon all Committee Democrats and a few Republicans expressed grave opposition to this schedule. By the end of the hearing Rep. Sensenbrenner agreed to postpone mark up for another week, i.e. into October.

Meanwhile, Sen. Patrick Leahy (D-VT), Chairman of the Senate Judiciary Committee, has already indicated that it might take his Committee weeks to pass a bill. The senate Judicial Committee was scheduled to hold a hearing on Tuesday, September 25, 2001.

Once tabled, ATA was widely attacked from liberal and conservatives alike. President George Bush has to come to its defense. On September 25, 2001, he advocated for the ATA in a policy speech at FBI:

"I hope Congress will listen to the wisdom of the proposals that the Attorney General brought up, to give the tools necessary to our agents in the field to find those who may think they want to disrupt America again. We're asking Congress for the authority to hold suspected terrorists who are in the process of being deported, until they're deported. That seems to make sense ...And we're asking for the authority to share information between intelligence operations and law enforcement ... the proposals we've made on Capitol Hill, carried by the Attorney General, has been carefully reviewed. They are measured requests, they are responsible requests, they are constitutional requests...And in order to win the war, we must make sure that

${ }^{108}$ Cyber rights groups urges defeat of 'Anti-Terrorism Act'http://groups.yahoo.com/group/portside/message/1413 
the law enforcement men and women have got the tools necessary, within the Constitution, to defeat the enemy." 109

On September 27, 2001, President Bush issued another statement in support at the CIA:

"I intend to continue to work with Congress to make sure that our law enforcement officials at home have got the tools necessary -- obviously, within the confines of our Constitution - to make sure the homeland is secure; to make sure America can live as peacefully as possible; to make sure that we run down every threat, take serious every incident. And we've got to make sure, as well, that those who work for the nation overseas have got the best available technologies and the best tools and the best funding possible."

On September 29, 2001, President, as consistent with his political style, was compelled to by pass the Congress and directly appeal to the people in his weekly radio address:

"I'm asking Congress for new law enforcement authority, to better track the communications of terrorists, and to detain suspected terrorists until the moment they are deported. I will also seek more funding and better technology for our country's intelligence community." ${ }^{110}$ transcript.

Meantime, on September 24, 2001, the House Judiciary Committee held a "briefing" for civil liberties groups regarding the ATA of 2001. ${ }^{111}$ As expected, critics of the ATA raised substantial civil rights concerns. ${ }^{112}$ Including:

109 "President: FBI Needs Tools to Track Down Terrorists: Remarks by the President to Employees at the Federal Bureau of Investigation, FBI Headquarters," For Immediate Release, Office of the Press Secretary, September 25, 2000 http://www.whitehouse.gov/news/releases/2001/09/20010925-5.html

${ }^{110}$ Radio Address of the President to the Nation, The White House, September 29, 2001.

111 The Chairman of the House Judiciary Committee, Rep. Sensenbrenner, did not want have Attorney General and the ACLU appearing the same day as co-equal.

${ }^{112}$ For a Congressional reaction to the ATA, see Brandon Spun, "Judiciary Committee Balks at Proposed Antiterrorism Act," Insight Magazine (Sept. 25, 2001), at http://www.citizenreviewonline.org/sept_2001/judiciary_committee.htm. (last visited 
James Dempsey as with Morton Halperin ${ }^{113}$ both objected to proposed changes to the Foreign Intelligence Surveillance Act (FISA) and associated electronic surveillance procedures. The CDT was also displeased with defining hacking as terrorism and allowing (authorizing and obligating) IPS to monitor clients account. ${ }^{114}$

While Greg Nojeim (ACLU) raised electronic surveillance issues, David Cole (Georgetown University Law Center) articulated immigration concerns. For Brad Jansen (Free Congress Foundation), he was concerned money laundering and forfeiture issues and Rachel King (ACLU) were concerned with criminal law problems. ${ }^{115}$

Finally, People For the American Way had called for public hearings on the administration's legislation, and urged members of Congress to pass legislation only when they adhered to three basic principles:

(1) The provisions should be carefully drafted to preserve constitutional liberties and to prevent abuse of power; (2) There should be meaningful judicial review and strict congressional oversight; (3) Anti-terrorism laws should be narrowly tailored to achieve clearly stated goals and objectives. ${ }^{116}$

November 26, 2003) (Rep. Jerrold Nadler (D-N.Y.) was unwilling to allow the AG to decide whether an alien should be detained indefinitely as national security threat. Rep. Barney Frank (D-Mass.) was concerned with allowing the FBI to spy on American, risking the "inappropriate release of information", as with the case Rev. Martin Luther King Jr. Judiciary Committee members Reps. Maxine Waters (D-Calif.) and Bob Barr (R-Ga.) did not want to rush the Patriot Act without the proper hearing and deliberation, since many of the provisions are very controversial (computer surveillance) and were rejected by the committee before.)

${ }^{113}$ Tech Law Journal Daily E-Mail Alert, September 25, 2001, 9:00 AM ET, Alert No. 272. http://www.techlawjournal.com/alert/2001/09/25.asp

${ }^{114}$ Declan McCullagh, "Anti-Terror Bill Not Done Yet," Wired News 02:00 AM Sep. 29, $2001 \mathrm{PT}$ http://www.wired.com/news/conflict/0,2100,47199,00.html

115 See, prepared statement of King.

116 "Bipartisan Anti-Terrorism Bill Abandoned in House, Civil Liberties Protections Sacrificed to Administration Pressure," http://www.citizenreviewonline.org/oct_2001/bipartisan_antiterrorism_bill.htm 
The AG's pushed for early adoption of ATA backfired for a number of reasons. First, the AG has failed to discuss with the White House and consulted with key administrative officials before making the ATA public. ${ }^{117}$ It was a very much behind the scene affairs by DOJ legal staff, under the leadership of Dinh. For example, Josh Bolten the deputy chief of staff of the White House was kept in the dark until the ninth hour. Likewise, the White House legal counsel's office and legislative affairs office was not advised. None of the government departments were advised, informed, notified or consulted over the ATA. They did not even have a copy of the proposal before Monday September 17, 2001. ${ }^{118}$

Second, the AG has failed to sought support from key Congressional leadership, choosing to adopt an us (administration) vs. them (the world court, Congress, interest groups, dissenters) attitude and take it or leave it approach. In this regard, the Bush administration has decided early on the USA PATRIOT ACT legislative process not to seek a negotiated compromise but preferred an imposed, all or nothing, solution. For example, the powerful Republic chairman of the Judiciary Committee, Sensenbrenner, heard about the ATA package on the morning of September 16, 2001 at home while Ashcroft was making the announcement on TV of things to come in a talk show. ${ }^{119}$ House Speaker Dennis Hasket was likewise not informed. ${ }^{120}$ Sensenbrenner was finally given a fax copy of the proposed ATA in the evening. ${ }^{121}$

The first sign of trouble came when Sensenbrenner informed Ashcroft that while he was eager to work with Ashcroft to produce a good legislation with bi-partisan support, his cooperation was not to be taken for granted. Still, the

\footnotetext{
${ }^{117}$ The Bill was not vetted by respective agencies through MBO but instead drafted by the DOJ lawyers alone; a most unusual process. AG Ashcroft and his DOJ staff did not even trust "loyal" and "constructive" comments of the other executive branch.

118 Steven Brill, After: How American Confronted the September 12 Era (N.Y.: Simon \& Shuster, 2003), p. 75. (Source Bolten, see p. 646).

${ }^{119}$ Steven Brill, After: How American Confronted the September 12 Era (N.Y.: Simon \& Shuster, 2003), p. 73. (Source Sensenbrenner, see p. 646).

${ }^{120}$ Steven Brill, After: How American Confronted the September 12 Era (N.Y.: Simon \& Shuster, 2003), p. 73. (Source Sensenbrenner, see p. 646). Hasket was unhappy at not being kept informed, much less being consulted, p. 74.

${ }^{121}$ Steven Brill, After: How American Confronted the September 12 Era (N.Y.: Simon $\&$ Shuster, 2003), p. 74 ( Source Sensenbrenner, see p. 646).
} 
Ashcroft was unyielding and unapologetic. ${ }^{122}$ To demonstrate his seriousness and power, Sensenbrenner insisted upon having the AG removed the suspension of habeas provision in the original ATA draft before the ATA could move forward. ${ }^{123}$

Third, the AG underestimated the political resistant he was to encounter, particularly from members of his own party, such as Bob Barr. He certainly did not anticipate ACLU joining cause with Bob Barr in seeking the delay, if not derailment, of the ATA. ${ }^{124}$ On September 21, 2001 (Friday), Bob Barr with four other members of the House Judiciary Committee sent a letter, drafted by ACLU, to Sensenbrenner listing their concerns with the ATA as proposed. The letter particularly listing ten provisions that required significant "further public debate" before adopted. ${ }^{125}$ These included: (1) wiretapping a cell phone number; (2) allowing for FISA order when "a" purpose of investigation was to obtain foreign intelligence; (3) authorizing "sneak and peek" search and seizure without notification to the suspect; (4) approving search warrant without probable cause; (5) allowing FBI to obtain Internet or library records in secret and without judicial oversight; (6) detaining non-citizens indefinitely; (7) allowing seizure of terrorists assets before hearing. ${ }^{126}$ The letter sealed the fate of earlier passage of the ATA as planned. By September 25, 2001 ATA was dead on arrival.

\section{The USA ACT}

The democratic response to ATA (later PATRIOT ACT) was the USA ACT Senate bill $1510^{128}$ introduced on October $4^{\text {th. }}{ }^{129}$ Originally it was to be

${ }^{122}$ Steven Brill, After: How American Confronted the September 12 Era (N.Y.: Simon \& Shuster, 2003), p. 74 ( Source Sensenbrenner, see p. 646).

${ }^{123}$ Steven Brill, After: How American Confronted the September 12 Era (N.Y.: Simon \& Shuster, 2003), p. 74 ( Source Sensenbrenner, see p. 646).

${ }^{124}$ Steven Brill, After: How American Confronted the September 12 Era (N.Y.: Simon \& Shuster, 2003), p. 121.

${ }^{125}$ Steven Brill, After: How American Confronted the September 12 Era (N.Y.: Simon \& Shuster, 2003), p. 121.

${ }^{126}$ Steven Brill, After: How American Confronted the September 12 Era (N.Y.: Simon \& Shuster, 2003), p. 121-122.

${ }^{127}$ Steven Brill, After: How American Confronted the September 12 Era (N.Y.: Simon \& Shuster, 2003), p. 122.

128 .1510 was introduced by Senator Daschle for himself and Senators Lott, Leahy, Hatch, Graham, Shelby and Sarbanes.

${ }^{129}$ Senator Leachy, Chairman of Senate Judiciary Committee along with the Democrat majority leader, Senator Daschle, and the Republican minority leader, Senator Lott, also 
tabled for a vote on October 9, 2004. But in the last minute, after an allnight negotiation by the Senate leadership the USA bill was withdrawn. A brand new "bi-partisan" bill was introduced. The majority leader, Senator Thomas Daschle of South Dakota, called for unanimous consent to bring the bill to a floor vote without debate or amendment. This was postponed for two days to accommodate Senator Feingold's amendments. ${ }^{130}$ The Senate finally passed the USA ACT on October 11th $2001{ }^{131}$ after a brief (4 hours) of debate. $^{132}$

The USA ACT was a negotiated anti-terrorism legislation between Democratic Chairman Patrick Leahy and Republican Ranking Member Orrin Hatch of the Senate Judiciary Committee and with the White House and the Department of Justice over a period of two weeks, before it was derailed. The negotiation was a difficult, tortuous and meandering one. The difficulties resulted as much from bitter partisanship in Senate as it is from an overbearing AG.

Partisanship was everywhere in evident. Senators voted along party line. For example, provisions that have been rejected by prior Republican Senators as encroachment on liberty under the Clinton administration was now embraced by the same Senators as promoting security of the nation post 9/11. "In fact, then Sen. Ashcroft voted to table that amendment, and my good friend from Utah, Senator Hatch, spoke against it and opined, "I do not

the chairmen of the Banking and Intelligence Committees, Senator Sarbanes, Senator Graham of Florida, Senator Hatch, and Senator Shelby introduced the USA ACT on October 4, 2001.

${ }^{130}$ Senate Debate on The Uniting and Strengthening America Act of 2001, Congressional Record: October 11, 2001 (Senate), Page S10547-S10630, S10570http:/www.fas.org/sgp/congress/2001/s101101.html

${ }^{131}$ While the final USA PATRIOT Act is much improvement over the original (September 19, 2001 MATA aka ATA) draft, it did not go far enough in protecting citizens' rights. For example, the original Administration proposal allowed the use of foreign law enforcement agencies wiretapped information in U.S. criminal proceedings against U.S. citizens; the freezing of non-criminal before trial and conviction; obtaining of educational records without a court order. All of them removed or revised in the final bill. "Statement of Senator Patrick Leahy The Uniting And Strengthening of America Act Of 2001 ("USA ACT")" (October 9, 2001) http://leahy.senate.gov/press/200110/100901a.html

${ }_{132}$ Senate Debate on The Uniting and Strengthening America Act of 2001, Congressional Record: October 11, 2001 (Senate), Page S10547-S10630 http://www.fas.org/sgp/congress/2001/s101101.html 
think we should expand the wiretap laws any further. " I recall Senator Hatch's concern then that "We must ensure that in our response to recent terrorist acts, we do not destroy the freedoms that we cherish."133

An overbearing AG was abundantly demonstrated by an AG who used 9/11 terrorism threat to make opposing lawmakers followed the Administration line, silently and compliantly. Those who spoke up to the Administration were not only considered as disloyal, but viewed as unpatriotic (in questioning the USA PATRIOT ACT.) An overbearing AG was also demonstrated by an AG who would not keep to his promise on negotiated anti-terrorism terms, and instead faulted the democrats for not acting fast enough to approve the Administration's frequently changed anti-terrorism bill. As recalled bitterly by Senator Leahy:

"On several key issues that are of particular concern to me, we had reached an agreement with the Administration on Sunday, September 30. Unfortunately, within two days, the Administration announced that it was reneging on the deal. I appreciate the complex task of considering the concerns and missions of multiple federal agencies, and that sometimes agreements must be modified as their implications are scrutinized by affected agencies." 134

For example, negotiated agreement on allowing for judicial supervision of grand jury testimony released to executive branch for intelligence purposes was reneged within two days of September 30. ${ }^{135}$

The USA ACT incorporate proposed provisions from Senator Leahy's initial package of the USA ACT; ${ }^{136}$ Intelligence Committee provisions sponsored by Intelligence Committee Chairman Bob Graham ${ }^{137}$ and committee

${ }^{133}$ Statement of Senator Patrick Leahy The Uniting And Strengthening of America Act Of 2001 ("USA ACT")" (October 9, 2001). para. 8.

${ }^{134} I d$. para. 9.

${ }^{135}$ Id. para.

${ }^{136}$ Mainly on securing Northern border, providing for the needs of victims and State and local law enforcement, and criminal law improvements. Leahy initial proposals were given to the AG on September 19, 2001, the day the AG unveiled his ATA effort. Id. Para. 5.

137 Senator Graham's Anti-Terrorism Bill: "Intelligence to Prevent Terrorism Act of 2001," Sept. 23, 2001. ttp://www.cdt.org/security/010923ipta.pdf 
member Dianne Feinstein; Banking Committee money laundering provisions $^{138}$ and other provisions proposed by other senators. The primary objective of the USA ACT was to seek a more balanced approach to provide security for the nation in the backdrop of $9 / 11$ through negotiation, compromise and above all else bi-partisan cooperation. As Senator Patrick Leahy put it:

This is not the bill that I, or any of the sponsors, would have written if compromise were unnecessary. Nor is the bill the Administration initially proposed and the Attorney General delivered to us on September 19, at a meeting in the Capitol.

We were able to refine and supplement the Administration's original proposal in a number of ways. The Administration accepted a number of the practical steps I had originally proposed on September 19 to improve our security on the Northern Border, assist our federal, state and local law enforcement officers and provide compensation to the victims of terrorist acts and to the public safety officers who gave their lives to protect ours. This USA Act also provides important checks on the proposed expansion of government powers that were not contained in the Attorney General's initial proposal.

In negotiations with the Administration, I have done my best to strike a reasonable balance between the need to address the threat of terrorism, which we all keenly feel at the present time, and the need to protect our constitutional freedoms. Despite my misgivings, I have consented to some of the Administration's proposals because it is important to preserve national unity in

${ }^{138}$ Senator Levine (D-MI), Hearing of Committee on Banking, Housing and Urban Affairs on Money Laundering and Terrorism, September 26, 2001.

http://levin.senate.gov/newsroom/release.cfm?id=211390 Terrorism was provided in Title III to USA PATRIOT ACT. 
this time of crisis and to move the legislative process forward.

The USA ACT, as proposed, was an unfinished business; a work in progress subject to further Party - Administration negotiation, House Judiciary Committee legislative proposals, ${ }^{140}$ court scrutiny (on Constitutionality), and Senate Judicial Committee oversight hearings (in practice). ${ }^{141}$

Substantively, the USA ACT was more comprehensive in scope, define in focus, integrative in approach and broad in operations. For example, in terms of scope, the ACT was not contented with giving the federal government more power to fighting terrorism but also seek to provide compensation for victims and liabilities for terrorism workers. ${ }^{142}$ In terms of focus, the ACT was not contended with paying lip service to protecting civil liberties and individual rights but also make clear that "hate crime" against Islamic people was not acceptable. ${ }^{143}$ In terms of integration, the ACT was not only relying on the federal government to fight terrorism but invite and

139 "Statement of Senator Patrick Leahy The Uniting And Strengthening of America Act Of 2001 ("USA ACT")" (October 9, 2001) http://leahy.senate.gov/press/200110/100901a.html

${ }^{140}$ The House version of the 'Uniting and Strengthening America Act' or the 'USA Act of 2001' was passed on October 12, 2001 (HR 3108). The House version of USA ACT was a compromise between the House PATRIOT ACT (HR2975) and Senate USA ACT (S. 1510) (passed on October 11, 2001). The majority staff who prepared the House USA ACT of 2001 was instructed to start with the Senate version of USA ACT and jettison provision that were not compatible, e.g. 5 years instead of 2 years sunset clause, since the Senate USA ACT itself was already a work of compromise incorporating many of the Administration desired provisions, during the last three weeks of negotiation. Some of the more significant provisions included: (1) provides for modernization of pen register and trap and trap law, i.e. authority to capture address not content; (2) provides for nation wide service of electronic warrant and terrorism warrant; (3) provides for "roving wiretap" of target's phone; (4) authorizes FISA wiretap after showing that terrorist investigation is "a significant" reasons; (5) provides for sharing of "foreign intelligence information", including grand jury testimony, between law enforcement and intelligence community, (6) expands ability to obtain business information with FISA order of certified to the court that information is relevant to foreign intelligence investigation; (7) provides for 5 years sunset of selected provisions. See Judiciary Committee Majority Staff Description of the House bill, as of Friday morning, Oct. 12, 2001. http://www.cdt.org/security/011012patriotinfo.pdf

141 "Statement of Senator Patrick Leahy The Uniting And Strengthening of America Act Of 2001 ("USA ACT")" (October 9, 2001). para. 4.

${ }^{142}$ See "VICTIMS" Id. para. 15 - 24, esp. 20.

${ }^{143}$ See "HATE CRME", para. 25 - 26, esp. 36. 
engage the state and local authority to local law enforcement authorities to play a key role. ${ }^{144}$ In terms of broadness, the ACT was not contended to fighting terrorism after the fact but sought to prevent terrorists from coming to the U.S. through strengthening the Northern border. ${ }^{145}$

The lone dissenter to the USA ACT was Senator Feingold (D-Wisconsin. His major concerns were four folds. First, the nation should not rush to judgment; haste makes waste. ${ }^{146}$ The Senate should take time to do things right, even if this means to slow down the process. Second, as a nation we should learn from history and not made the same mistakes we did when we passed the Alien and Sedition Acts and suspended habeas corpus during the Civil War, interned Japanese-Americans during World War II, blacklisted communist sympathizers during the McCarthy era, and harassed antiwar protesters during the Vietnam war. ${ }^{147}$ Third, the Senate has an important Constitutional role to play in providing meaningful scrutiny for the bill. ${ }^{148}$ Fourth, the Administration should not be allowed to use the occasion to seek unlimited powers. ${ }^{149}$ Fifth, the nation should fight security without destroying civil liberties.

Specifically, Feingold supported the idea of "roving wiretaps" but objected to its indiscriminate application to situation to permit eavesdrop when the targeted person is not the one using the phone. He objected to allowing the police to have access to any typed or stored or "tangible" information with administrative order, except under court supervision. He objected to "sneak and peek" which allowed the police to search people's place without notifying the person. He objected to allow system administrators at

\footnotetext{
${ }^{144}$ See "STATE AND LOCAL LAW ENFORCEMENT", para. 27 - 37.

${ }^{145}$ See "NORTHERN BORDERS" Id. para. 38 to 42, esp. $40-42$.

146 Senate Debate on The Uniting and Strengthening America Act of 2001, Congressional Record: October 11, 2001 (Senate), Page S10547-S10630, S10571 ("But I still believe we needed a more deliberative process on this bill, and more careful consideration of the civil liberties implication of it.") http://www.fas.org/sgp/congress/2001/s101101.html ${ }^{147} \mathrm{I} d$.

${ }^{148} I d$. ("We took an oath to support and defend the Constitution of the United States. In these difficult times that oath becomes all the more significant.")

${ }^{149} I d$. ("Why does the administration insist on leaving open the possibility that this provision will be abused to entirely eliminate the privacy of students' and library patrons' computer communications? Is there a hidden agenda here? ")
} 
universities or libraries to monitor private net activities of "computer trespasser." 150

When USA ACT came to a floor vote, Senate Feingold negotiated for three amendments, all of them were defeated, though not without some consoling support from colleagues.

\section{FROM PATRIOT ACT to USA PATRIOAT ACT}

The current USA PATRIOT ACT found its genesis in the PATRIOT ACT, introduced as House bill 2975 on October 2, 2001. ${ }^{151}$ The PATRIOT ACT incorporated most of the administration ATA provisions and expanded on them. ${ }^{152}$ The PATRIOT ACT was the negotiated produce of In the Republican Congressman Jim Sensenbrenner of Wisconsin, Chairman of the Judiciary Committee, and Ranking Democrat from Michigan, John Conyers, the ranking Democrat. "On October 12, 2001, after another all-night drafting session, a text was produced that had only minor changes from the Senate-passed bill. It was rushed to the floor and passed with only three Republican and 75 Democratic votes in opposition. Thus by Friday, October 12 , both houses had passed nearly identical antiterrorism bills."

House and senate leaders work to resolve the differences between HR2975 and S1510. The work was interpreted by anthrax attack on the Hill. Issues were unresolved for a week.

150 “A Senator's Lonely Privacy Fight," Wired News: 06:08 AM Oct. 11, 2001 PT http://www.wired.com/news/conflict/0,2100,47490,00.html?tw=wn_story related ${ }^{151}$ Substantively, the PATRIOT ACT (HR 2975) was based on Administrative antiterrorism proposals contained in CTA, MATA, ATA. H.R. 2975 - Provide Appropriate Tools Required To Intercept and Obstruct Terrorism (PATRIOT) Act (Rep.

Sensenbrenner (R) Wisconsin). Oct. 12, 2001. OBM. ("H.R. 2975 includes the provisions proposed by the Administration in three main areas: (1) information gathering and sharing; (2) substantive criminal law and criminal procedure; and (3) immigration procedures.") http://www.whitehouse.gov/omb/legislative/sap/107-1/HR2975-h.html Procedurally: A version of H.R. 2975 was passed by the House Committee on the Judiciary 36 to nothing. The House then passed H.R. 2975 by a vote of 337 to 79. ${ }^{152}$.R. 2975 was introduced by Representative Sensenbrenner for himself and Representatives Conyers, Hyde, Coble, Goodlatte, Jenkins, Jackson-Lee, Cannon, Meehan, Graham, Bachus, Wexler, Hostettler, Keller, Issa, Hart, Flake, Schiff, Thomas, Goss, Rangel, Berman and Lofgren. S.1510 by Senator Daschle for himself and Senators Lott, Leahy, Hatch, Graham, Shelby and Sarbanes. 
The negotiation and compromise between the House (HR2975) and Senate (S1510) fell in the following areas:

Major compromise between House and Senate PATRIOT Bill

\begin{tabular}{|c|c|c|c|}
\hline Provisions & $\begin{array}{c}\text { Original House } \\
\text { version }\end{array}$ & Senate version & Compromise \\
\hline Sunset clause & 5 years & None & 4 years \\
\hline McDades law $^{153}$ & None & $\begin{array}{l}\text { Revisions to } \\
\text { McDade }\end{array}$ & None \\
\hline $\begin{array}{l}\text { Money } \\
\text { laundering } \\
\text { provisions }\end{array}$ & None & None & $\begin{array}{l}\text { Comprehensive } \\
\text { Money } \\
\text { laundering } \\
\text { provisions }\end{array}$ \\
\hline $\begin{array}{l}\text { Information- } \\
\text { sharing } \\
{ }^{154} \text { provisions }{ }^{155}\end{array}$ & $\begin{array}{l}\text { Sharing } \\
\text { information } \\
\text { subject to prior } \\
\text { court } \\
\text { authorization }\end{array}$ & $\begin{array}{l}\text { Sharing } \\
\text { information } \\
\text { without notice to } \\
\text { court }\end{array}$ & $\begin{array}{l}\text { Sharing with } \\
\text { notice to the } \\
\text { court after } \\
\text { disclosure. }\end{array}$ \\
\hline $\begin{array}{l}\text { Electronic } \\
\text { surveillance } \\
\text { note }\end{array}$ & None & None & $\begin{array}{l}\text { Ex parte and in } \\
\text { camera notice } \\
\text { with the court } \\
\text { when a lawful } \\
\text { pen register or } \\
\text { trap and trace } \\
\text { order is install on } \\
\text { ISP. }\end{array}$ \\
\hline $\begin{array}{l}\text { Certification of } \\
\text { alien as } \\
\text { terrorists }\end{array}$ & $\begin{array}{l}\text { Declaration of } \\
\text { alien as terrorist } \\
\text { limited to Deputy } \\
\text { AG }\end{array}$ & $\begin{array}{l}\text { Declaration of } \\
\text { alien as terrorist } \\
\text { limited to } \\
\text { Commissioner of } \\
\text { INS }\end{array}$ & $\begin{array}{l}\text { Declaration of } \\
\text { alien as terrorist } \\
\text { limited to Deputy } \\
\text { AG. }\end{array}$ \\
\hline $\begin{array}{l}\text { Revisit of alien } \\
\text { terrorists } \\
\text { certification }\end{array}$ & $\begin{array}{l}\text { Revisit of alien } \\
\text { terrorists } \\
\text { certification }\end{array}$ & None & $\begin{array}{l}\text { Revisit of alien } \\
\text { terrorists } \\
\text { certification }\end{array}$ \\
\hline
\end{tabular}

153 The McDade law requires federal prosecutors to comply with state ethics laws.

154 Sharing of grand jury information.

${ }^{155}$ Between law enforcement and intelligence community. 


\begin{tabular}{|l|l|l|l|}
\hline $\begin{array}{l}\text { Electronic } \\
\text { tacking of } \\
\text { foreign students }\end{array}$ & every 6 months. & None & $\begin{array}{l}\text { every 6 months } \\
\text { Authorized 36 } \\
\text { millions for } \\
\text { implementation } \\
\text { of SEVIS. }\end{array}$ \\
\hline $\begin{array}{l}\text { Accountability: } \\
\text { Inspection }\end{array}$ & None & None & $\begin{array}{l}\text { Established } \\
\text { Inspector General } \\
\text { for Civil } \\
\text { Liberties and } \\
\text { Civil Rights } \\
\text { inside the } \\
\text { Department of } \\
\text { Justice. }\end{array}$ \\
\hline $\begin{array}{l}\text { Accountability: } \\
\text { Court liability }\end{array}$ & None & None & $\begin{array}{l}\text { Provide for } \\
\text { Federal tort relief } \\
\text { for improper } \\
\text { government } \\
\text { release of wiretap } \\
\text { information. }\end{array}$ \\
\hline
\end{tabular}

Source: Extracted form House floor debate, USA PATRIOT ACT, October 23, 2001. Congressional Record: October 23, 2001 (House) Page H7159H7207

On October $23^{\text {rd }} 1001$, the USA PATRIOT ACT was debated in the House for one hour. The major objections concerned two major issues: i.e. legislative procedure and due process:

First the legislative process was considered highly usual and irregular. The draft bill was reported out the House Judiciary Committee 36-0. But that bill was jettisoned in lieu of a new one negotiated by the Congressional leadership and behind closed door, without input from the Committee or House members. The Congressional members were informed of the change, afterward. Each Party was given two copies of the bill shortly before the floor debate on October 23, 2001. No amendments were entertained. The debate was held late at night and after working hours. As a result most members were ignorant of the content of the bill when asked to vote on the it. Representative Frank (D - Mass.) found the process unacceptable:

There is no reason why we could not have had this open to amendment tonight. This bill should not be debated now. Was it 
really necessary to debate one of the most profound pieces of legislation and its impact on our society that we have had, was it really necessary to debate it at night after all of the Members who have been working all day were told to go home? Why could this not have been a full-fledged debate with some amendments? ${ }^{156}$

Mr. Conyers likewise complained:

The members of the Committee on the Judiciary had a free and open debate; and we came to a bill that even though imperfect, was unanimously agreed on. That was removed from us, and we are now debating at this hour of night, with only two copies of the bill that we are being asked to vote on available to Members on this side of the aisle. I am hoping on the other side of the aisle they at least have two copies...there is something wrong with that process....79 Members were not able to go along with the bill, is that a legislative body that does not debate is being railroaded whether they know it or not, whether they want to accede to it or not. ${ }^{157}$

Some members also complaint of the lack of due process for citizens and likely abuse of power by the government. For example, Representative Jackson - Lee (D - Texas) was heard to complained:

Mr. Speaker, I think Americans know very well that character is judged not so much on how a man or woman acts in the good times, but how we act in the face of adversity ...I do believe that in making our country safe against terrorism, that we do not necessarily need to do away with due process, and that we should not target innocent people unfairly because of their race, color, sexual orientation, creed, gender, or religion. ${ }^{158}$

Other criticism was more pointed and specific. For example, Mr Scott (DVA) ${ }^{159}$ observed that:

${ }^{156}$ USA PATRIOT ACT, House floor debate, Congressional Record: October 23, 2001 (House) Page H7159-H7207

157

158 Id. 7203

${ }^{159}$ Congressional Record: October 23, 2001 (House), Page H7159-H7207, 7201. 
First, the new wiretap power was not limited to intelligence gathering but broad enough to be used to investigate common crime and innocent citizens;

Second, there were very little protection against the abusive use of wire tape, e.g. no probable caused is required for foreign intelligence search warrant.

Third, pen register and track and trace violate people's privacy right and protection form government search and seizure power;

Fourth. the government was allowed to conduct secret searches, so-called sneak and peak without telling the target. ${ }^{160}$

Finally, on October 25th the final bill, HR 3162, the "USA PATRIOT ACT" was debate in the Senate and passed. ${ }^{161}$ The floor debate was a tightly managed one. Except for Senator Feingold, only those who were involved in the drafting or negotiation process were allowed to participate in the debate. "The PRESIDENT pro tempore. The chairman and ranking member of the Judiciary Committee have 90 minutes each; the Senator from Michigan, Mr. Levin, has 10 minutes; the Senator from Minnesota, Mr. Wellstone, has 10 minutes; the Senator from Maryland, Mr. Sarbanes, has 20 minutes; the Senator from Wisconsin, Mr. Feingold, has 1 hour; the Senator from Florida, Mr. Graham, has 15 minutes; and the Senator from Pennsylvania, Mr. Specter, has 15 minutes." 162

Senator Leady open the debate with the emphatic observation that the bill was a hard earned compromise: "This was not the bill that I, or any of the sponsors, would have written if compromise was unnecessary. Nor was it the bill the Administration had initially proposed and the Attorney General delivered to us on September 19, at a meeting in the Capitol."163

160 Op Cit. 7201.

161 The ACT was passed without a conference with the House, who passed a similar bill a day earlier.

${ }^{162}$ USA PATRIOT ACT, Floor Debate, Congressional Record: October 25, 2001 (Senate), Page S10990-S11060; From the Congressional Record Online via GPO Access [wais.access.gpo.gov] [DOCID:cr25oc01-91]. (USA PATRIOT ACT, Floor Debate). ${ }^{163}$ Id. Page S10991. 
He was also quick to point out that: First, the bill was a much improved legislation from the September 19, 2001 Administration proposal (ATA MATA); Second, that both of Senate and Administration has made much concession; Third, that important safeguard was in place against government abuse of power and protection of rights; Fourth, that the bill, even if passed, would be a work in progress, subject to supervision by court and monitoring by Senate, revisions and amendments along the way.

As to improvements, the Senator named ten areas that the ACT has improved from the Administrative proposal of September 19, 2001: ${ }^{164}$

First, improved security on the Northern Border; Second, added money laundering provisions; Third, added programs to enhance information sharing and coordination with State and local law enforcement, grants to State and local governments to respond to bioterrorism, and to increase payments to families of fallen firefighters, police officers and other public safety workers; Fourth, added humanitarian relief to immigrant victims of the September 11 terrorist attacks;

Fifth, added help to the FBI to hire translators;

Sixth, added more comprehensive victims assistance;

Seventh, added measures to fight cybercrime;

Eighth, added measures to fight terrorism against mass transportation systems;

Ninth, added important measures to use technology to make our borders more secure;

Tenth, able to include additional important checks on the proposed expansion of government powers contained in the Attorney General's initial proposal. ${ }^{165}$

As to supervision and oversight. Senator Leahy observed:

"I do believe that some of the provisions contained both in this bill and the original USA Act will face difficult tests in the courts, and that we in Congress may have to revisit these issues at some time in the future when the present crisis has passed, the sunset has expired or the courts find an infirmity in these

$164 \mathrm{~S} 10091$.

${ }^{165} \mathrm{Id}$. (verbatim quotes). 
provisions. I also intend as Chairman of the Judiciary

Committee to exercise careful oversight of how the Department

of Justice, the FBI and other executive branch agencies are

using the newly-expanded powers that this bill will give them. I

know that other members of the Judiciary Committee-

including Senator Specter, Senator Grassley, and Senator

Durbin--appreciate the importance of such oversight. ${ }^{166}$

It was signed into law by President G.W. Bush on October 26th.

\section{III \\ A Failure of Process?}

There is a common perception that the USA PATRIOT ACT registered a failure of legislative process, citing a lack of public information, official consultation and Congressional scrutiny. When the USA PATRIOT ACT came before the House of Representative on October 23, 2001, Representative Scott has this to say:

First of all, I think it is appropriate to comment on the process by which the bill is coming to us. This is not the bill that was reported and deliberated on in the Committee on the Judiciary. It came to us late on the floor. No one has really had an opportunity to look at the bill to see what is in it since we have been out of our offices. The report has just come to us. It would be helpful if we would wait for some period of time so that we can at least review what we are voting on, but I guess that is not going to stop us, so here we are. ${ }^{167}$

An interesting research issues presented itself: To what extent and in what manner did the final USA PATRIOT ACT incorporated public sentiments and reflected popular interests, e.g. how was the positions of various interest groups or perspectives of affected parties taken into account? In a broader context, what was the role and contribution of various interest groups in shaping the content and process of USA PATRIOT ACT, originated as ATA? For example, ACLU working with Bob Bar in the House and in the

${ }^{166} \mathrm{~S} 10091-2$.

167 "House Debate on USA PATRIOT Act" Congressional Record: October 23, 2001

(House) Page H7159-H7207. http://www.fas.org/sgp/congress/2001/h102301.html 
Senate was able to alter the course and tamper the thrust of the ATA. Many progressive and conservatives non-profit groups have worked to cut back the scope and reach of the PATRIOT Act, including: (1) People for American Way Foundation. PFAWF founded was 1981 by Norman Lear, Barbara Jordan and others "to counter the growing clout and divisive message of right-wing televangelists, including Jerry Falwell, Pat Robertson and Jimmy Swaggart." Since then it has worked against the spread and influence of Radial Right, e.g. challenged the nomination of Judge Bork to the Supreme Court (1987) or worked against preaching of creationism (2001). ${ }^{168}$ PFAWF position on and contribution to USA PATRIOT Act is best captured by PFAWF's letter to Congress: "Letter from Ralph G. Neas to Congress on Anti-Terrorism Legislation," (October 9, 2001):

"In our October 1 letter to all Members of Congress, we urge that any amendments and the final legislation reflect the following principles: Language should be carefully crafted in order to preserve constitutional liberties and to prevent the creation of overly broad powers that could lead to abuse. Meaningful judicial review and oversight should not be shortcircuited. Anti-terrorism laws should be narrowly tailored to that purpose. In particular, we are mindful of the importance of these issues and their scope in final legislation: a narrowly tailored definition of terrorism which does not inadvertently include domestic acts of civil disobedience or other non-violent activity; clear language exempting the content of Internet communications from pen register surveillance; meaningful judicial oversight of any new law enforcement powers for purposes of surveillance of telephone and Internet communications; meaningful judicial oversight of information sharing between intelligence and law enforcement agencies, coupled with clear separation and a very high wall between wiretapping conducted for foreign intelligence surveillance, and that conducted for domestic criminal investigations; and full due process, including access to counsel and habeas proceedings, and meaningful limitations on detention prior to and after filing of charges against alien suspects. Lastly, the

168 "People for American Way Foundation: A history"

http://www.pfaw.org/pfaw/general/default.aspx?oId=4976 
sunset provisions in the House bill would improve the final version of this legislation, independent of its content." 169

With regard to the USA PATRIOT ACT, the $\mathrm{CDT}^{170}$ sought to bring a balanced perspective to the anti-terrorism legislation by testifying before Congress, acting as clearing house for drafts and analysis, consulting with Congressional staff over various drafts; working with other Internet industrial and interest groups. CDT was successful in resisting "technology mandate" (Section 216), narrowing "computer trespasser" provision, and arguing for a "sunset" clause. CDT is also monitoring the implementation of the USA PATRIOT ACT through its Digital Privacy Working Group and Internet Caucus Advisory Committee under the auspices of the CDT Congressional Internet Caucus' reacting with Congressional oversight, court litigations, FOIA requests, public education and liaison with various civil liberties groups, if need be. ${ }^{171}$

The only public feedback on the ACT came in the form of letters to individual Congressman ${ }^{172}$ or Editorials in the Newspaper. For example, on September 25, 2001 an editorial entitled "EDITORIAL: Why the rush?" in the St. Petersburg Times (Florida) ${ }^{173}$ observed that House Judiciary Committee Chairman F. James Sensenbrenner Jr. (R-Wis) was rushing the ATA of 2001 through Congress and the Justice Department was suspected of

169 http://www.pfaw.org/pfaw/general/default.aspx?oid=2322

170 The Center for Democracy and Technology. CDT is a 501 (c) (3) non-profit public policy organization dedicated to promoting the free and open access to global Internet. See "CDT Principles" http://www.cdt.org/mission/principles.shtml The Mission of CDT is: "The Center for Democracy and Technology works to promote democratic values and constitutional liberties in the digital age ... CDT seeks practical solutions to enhance free expression and privacy in global communications technologies." See "CDT Mission" http://www.cdt.org/mission/ To this end, the CDT promotes "Free Expression," protects "Information Privacy," and resists "Electronic Surveillance" in the net. See "CDT Activities". http://www.cdt.org/mission/activities.shtml ${ }^{171}$ See "Network Security and Government Surveillance," at page 4 of "Summary of Activities 2001 and Work Plan 2002," The Center for Democracy and Technology. January 2002. http://www.cdt.org/mission/

${ }^{172}$ Sonia Arrison is the director of the Center for Freedom and Technology at the San Francisco-based Pacific Research Institute, "OPINION, "New anti-terrorism law goes too far." The San Diego Union-Tribune, October 31, 2001, Wednesday, Pg. B-9, 791 words. (Defending the nation against terrorist acts can and should be done without eroding America's liberties.)

${ }^{173}$ EDITORIAL: Why the rush?" St. Petersburg Times (Florida) September 25, 2001, Tuesday, 0 South Pinellas Edition, Pg. 10A, 505. 
using 9/11 to get many of the powers it failed to obtain from Congress in the past. Observing: "Congress needs to slow down and get this right." Another editorial - "An improved antiterrorism bill" - a week later (October 3, 2001) in the same page ${ }^{174}$ observed that Congressional leaders of both parties were doing their best in crafting a compromised ATA that would give law enforcement more tools to combat terrorism while protecting civil liberties. There were many others editorials during the legislative period, e.g. an editorial in the The Washington Post : "Stampeded in the House," the House Republican leadership in bypassing the legislative process in forcing a vote on a major anti-terrorism bill (USA PATRIOT ACT) that was anonymously drafted the night before without Judiciary Committee approval, in lieu of one that was unanimously approved by the House Judiciary Committee. On the day the USA PATRIOT ACT was passed, October 26, 2001, the Denver Post published an editorial; "EDITORIAL Proceed with caution," The Denver Post ${ }^{176}$ : "We hope that the executive branch and Congress will be especially vigilant to make sure that, in the rush to defeat terrorism, they don't turn a free country into a virtual prison."

Feedback from special interest groups, e.g. ACLU or CDC, came with many, blow by blow analysis of anti-terrorism legislations when the legislation moved through the Congress. But none of these NGOs were invited to submit their comments, officially. There is no telling if any of them received the attention or consideration of the administration, if at all. ${ }^{177}$

The pressure to act expeditiously came from the administration as well as Congressional members. ${ }^{178}$ The Attorney General threatened the Congress

174 “EDITORIAL: An improved antiterrorism bill," St. Petersburg Times

(Florida), October 03, 2001, Wednesday, Pg. 14A, 650 words.

175 the "EDITORIAL: Stampeded in the House," The Washington Post October 16, 2001, Tuesday, Final Edition, Pg. A22, 541 words.

176 "EDITORIAL Proceed with caution," The Denver Post October 26, 2001 Friday, Pg. B-06, 458 words.

${ }^{177}$ For example, "EFF: Analysis of Anti-Terrorism Act (ATA) of 2001," Electronic Frontier Foundation (Sep. 27, 2001) (ATA's expands FISA powers to cover nonterrorism cases and increase surveillance of U.S. citizens and non-citizens alike.) http://www.eff.org/Censorship/Terrorism militias/20010927 eff ata analysis.html;

${ }^{178}$ The same thing happened with the establishment of the homeland security. Rapp, D. "Editorial: The Scare Factor," CQ Weekly Vol. 60 no. 27 (July 6 2002) p. 1792 (Observing that the Congress is incapable of orderly legislating except in time of crisis, as spurred by external events and driven by "Scare factor.") http://80- 
with dire circumstances if anti-terrorism measures were not passed, in a timely manner (in days not weeks). Senator Hatch wanted the Senate to act quickly:

"We should not let some of the petty aspects of this body stand in the way, not passing this type of legislation right now when it is really needed, on the day that, for the first time in my 25 years, a vote was interrupted by a bomb threat and we all had to move outside.... It is time to start fixing these laws. We can play around with commissions. We can play around with task forces. We can do a lot of other things, but I would like to fix it now." 179

\section{IV}

\section{A Preliminary Assessment}

The biggest concern with the USA PATRIOT ACT, from friends and foes alike, was that the Administration's original bill (MATA) was not developed in response to the events of $9 / 11$. Many of the measures have nothing to do with ratifying pre 9/11 intelligence failure of improving our post 9/11 counter-terrorism efforts. For example, most of the Administration's anti-terrorism measures could be equally applied domestically for criminal investigation, e.g. use of FSIA warrant to investigate organized crime. The Administration bitterly resisted any attempt to restrict and limit the application of anti-terrorism provisions to specific situations, preferring instead to ask for broad and sometimes unlimited powers.

More damningly, the Administration resisted every reasonable effort to find an accommodation between Administration's perceived security needs and the nation's real civil liberty concerns. The Administration was not in the mood of negotiation, many of the important and reasonable proposals were rejected, without examination and discussion. For example, the Congress was prepared to provide interim emergency authority for the Administration

vnweb.hwwilsonweb.com.www.remote.uwosh.edu:2048/hww/shared/shared_main.jhtml; jsessionid=MDAM1BYYF54GPQA3DIMCFFWADUNBIIV0? requestid=78525

${ }^{179}$ Senate floor debate on wiretap and anti-terrorism proposals DEPARTMENTS OF COMMERCE, JUSTICE, AND STATE, THE JUDICIARY, AND RELATED AGENCIES APPROPRIATIONS ACT, 2002--Continued -- (Senate - September 13, 2001). http://www.cdt.org/security/010913senatewiretap.shtml 
pending more in-depth study of counter-terrorism and Homeland Security needs. This was declined by the Administration, e.g. in case of grand jury information sharing judges could be asked to order such disclosure to save lives. $^{180}$

The ACT consisted of provisions that had long rested in the files of the lawenforcement and intelligence agencies waiting for the right moment. ${ }^{181}$ But even Attorney General John Ashcroft, who as a senator had expressed great skepticism about many of these items, now insisted that Congress act within a week. $^{182}$

The ACT was not formally submitted by the Administration, since that would have required a review process coordinated by the Office of Management and Budget--a procedure that would have provided an opportunity for all concerned agencies to provide comments. ${ }^{183}$

The USA PATRIOT ACT passed the Congress with an overwhelming major, i.e. 356-66 in the House and 98-1 in the Senate and in record time

${ }^{180}$ Morton H. Halperin, "Less Secure, Less Free," The American Prospect vol. 12 no. 20, November 19, 2001

${ }^{181}$ Senator Kye: "legislation dealing with these issues. There have been numerous hearings about these issues. They were in effect lying on the table waiting for us to deal with them. Unfortunately, it is the case that even though from time to time we have put some of these ideas out, there has always been a reason not to do it, to wait, to defer, to hold off on that, and that we will have a comprehensive look at this or whatever it might be." Congressional Record: September 13, 2001 (Senate), Page S9362-S9387 DEPARTMENTS OF COMMERCE, JUSTICE, AND STATE, THE JUDICIARY, AND RELATED AGENCIES APPROPRIATIONS ACT, 2002, Amendment No. 1562. http://www.fas.org/sgp/congress/2001/s091301.html The point Senator Kye tried to make in context was that the proposed Amendment No. 1562 contained no new ideas and have been extensively studied and debated before. In fact many of the provisions were recommended by the "COUNTERING THE CHANGING THREAT OF INTERNATIONAL TERRORISM: Report of the National Commission on Terrorism." Chaired by Ambassador L. Paul Bremer III http://www.fas.org/irp/threat/commission.html The Commission was created by law (Pursuant to Public Law 277, 105th Congress) and charged by Congress to investigate and evaluate "America's laws, policies, and practices for preventing and punishing terrorism directed at American citizens."

${ }^{182}$ Morton H. Halperin, “The Liberties We Defend," American Prospect Vol. 12, No. 18 Oct. 22, 2001. http://www.prospect.org/print/V12/18/halperin-m-2.html

${ }^{183}$ Morton H. Halperin, "Less Secure, Less Free , “American Prospect Vol. 12, No. 20, Nov. 19, 2001. http://www.prospect.org/print/V12/20/halperin-m.html 
(six weeks - 9/19 to 10/26/2001), with the nation laboring in a war time environment and Congress operating with a siege mentality.

As to the process, there were no time for public consultation, ${ }^{184}$ community feedbacks, professional input, and Congressional scrutiny. ${ }^{185}$ Not only were there no consultation, the public has a difficulty in obtaining the necessary information to formulate an informed judgment on the issues involved.

The position taken up by Feingold best summed the concerns raised by issues presented by the whole USA PATRIOT ACT process from beginning to end. Senator Russ Feingold, chairman of the Constitution Subcommittee of the Judiciary Committee, was consistent in expressing his reservations about the USA PATRIOT Act (H.R. 3162), in content and process, in his statement on the Senate Floor on October 25, 2001 in casting his lone dissenting vote.

The Senator called upon the National, Congress and public to "continue to respect our Constitution and protect our civil liberties in the wake of the

${ }^{184}$ It is extremely difficult for UUA and other organization to obtain information on the Patriot Act, then being considered behind closed door. UUA Washington Office. http://www.witnessforcivilliberties.org/doc/education/factsheetspatriotact.pdf

See also "USA PATRIOT ACT: A Summary of ALA activities," ALA Washington Office, January 19, 2002. (The ALA has to be kept informed about the progress and language of the Patriot Act through informal channels, e.g. via Congressional staffers.) http://www.ala.org/Content/NavigationMenu/Our Association/Offices/ALA Washington Issues2/Civil Liberties, Intellectual Freedom, Privacy/The USA Patriot Act and Lib raries/background.pdf

${ }^{185}$ For a contrary observation, see Orrin G. Hatch, Square Peg: Confessions of a Citizen Senator (Basic Books, 2002) (There were much debate and discussion behind close door by Congressional leadership and staff alike. See pp. 80-90). The Patriot Act did have hearings and discussion in the House, but the House anti-terrorism bill was ignored for the Senate version, by fiat. Similarly, there were time set aside for presentation of views of individual Senators on the Patriot Act in the Senate on October 25, 2001 (The chairman and ranking member of the Judiciary Committee have 90 minutes each; the Senator from Michigan, Mr. Levin, has 10 minutes; the Senator from Minnesota, Mr. Wellstone, has 10 minutes; the Senator from Maryland, Mr. Sarbanes, has 20 minutes; the Senator from Wisconsin, Mr. Feingold, has 1 hour; the Senator from Florida, Mr. Graham, has 15 minutes; and the Senator from Pennsylvania, Mr. Specter, has 15 minutes) but the Patriot Act was destined to pass on October 25, 2001, notwithstanding objections. See Congressional Record: October 25, 2001 (Senate), Page S10990-S11060. http://www.cdt.org/security/011025senate.txt 
attacks" and cautioned against "the mistreatment of Arab Americans, Muslim Americans, South Asians, or others in this country."

Senate Feingold reminded the Nation that "wartime has sometimes brought us the greatest tests of our Bill of Rights", giving such examples as the passage of "Alien and Sedition Acts [of 1798], the suspension of habeas corpus during the Civil War, the internment of Japanese-Americans, German-Americans, and Italian-Americans during World War II, the blacklisting of supposed communist sympathizers during the McCarthy era, and the surveillance and harassment of antiwar protesters, including Dr. Martin Luther King Jr., during the Vietnam War."

The Senator objected to the USA PATRIOT Act on philosophical, procedural and substantive grounds:

Philosophically, Feingold was against trading liberties for security:

"Of course, there is no doubt that if we lived in a police state, it would be easier to catch terrorists. If we lived in a country that allowed the police to search your home at any time for any reason; if we lived in a country that allowed the government to open your mail, eavesdrop on your phone conversations, or intercept your email communications; if we lived in a country that allowed the government to hold people in jail indefinitely based on what they write or think, or based on mere suspicion that they are up to no good, then the government would no doubt discover and arrest more terrorists. But that probably would not be a country in which we would want to live. And that would not be a country for which we could, in good conscience, ask our young people to fight and die. In short, that would not be America. Preserving our freedom is one of the main reasons that we are now engaged in this new war on terrorism. We will lose that war without firing a shot if we sacrifice the liberties of the American people."187

186 "Statement Of U.S. Senator Russ Feingold On The Anti-Terrorism Bill From The Senate Floor," October 25, 2001

${ }^{187} \mathrm{Id}$. 
Procedurally, he was against to rushing the USA PATRIOT Act through Congress:

"You may remember that the Attorney General ...provided the text of the bill the following Wednesday, and urged Congress to enact it by the end of the week....the pressure to move on this bill quickly, without deliberation and debate, has been relentless ever since...It is one thing to shortcut the legislative process in order to get federal financial aid to the cities hit by terrorism...It is quite another to press for the enactment of sweeping new powers for law enforcement that directly affect the civil liberties of the American people without due deliberation by the peoples' elected representatives." 188

The AG was quick to rebut the charge and defend the process:

Well, frankly, I don't know that I-it might be better to allow different Members to ask specific questions. I do want to recognize the fact that over the course of the last maybe 10 days, I've been working with individuals from the Minority Leader of the House to the Committee Chairman in the Senate. We've had lots of time together. The Ranking Member and I have spent time together. The Chairman and I have spent time together. We've invited the leadership of Committees of both Houses to confer with us about this measure, and we-we believe that this is a measure that should - that is the result of collaborative effort and work, and so there is reason for us to have substantial agreements. ${ }^{189}$

Substantively, Feingold was of opinion that the USA PATRIOT ACT ("bill") failed to "strike the right balance between empowering law enforcement and protecting civil liberties."

Particularly, he has the following objections: ${ }^{190}$

${ }^{188} \mathrm{Id}$.

${ }^{189} \mathrm{http}: / /$ commdocs.house.gov/committees/judiciary/hju75288.000/hju75288 0.HTM

190 Feingold was supportive of many provisions in the Bill, including: FBI should be able to seize voice mail messages as well as tap a phone; Federal criminal law on the possession and use of biological weapons should be re-written; Cables communication should be treated the same as phone lines communication; Penalties of terrorist crimes 
(1) The bill gives the law enforcement agencies new and expansive powers to investigate not only terrorism but other crimes, e.g. the "sneak and peak" warrant. Government can now avoid the stricture and protection of the Fourth Amendment by claiming "reasonable cause to believe" that providing notice to searched suspects "may" "seriously jeopardize an investigation."

(3) The bill allows law enforcement to monitor a computer with the permission of its owner or operator, but without warrant or probable cause, e.g. unauthorized use of company or library computers by employees or patrons.

(4) The bill allows the use of Foreign Intelligence Surveillance Act (FISA) investigative powers, without meeting the rigorous probable cause standard under the Fourth Amendment, if the government can show that intelligence is a "significant purpose" of the investigation, even if criminal investigation is the primary purpose.

(4) The bill allows the use of FISA to compel the production of records from any business regarding any person, if that information is sought in connection with an investigation of terrorism or espionage. This allows the he government to go on a fishing expedition.

(5) The original ATA allows the Attorney General extraordinary powers to detain immigrants indefinitely, including legal permanent residents on "mere suspicion" that the person is engaged in terrorism. The bill requires the Attorney General to charge the immigrant within seven days. It further required Attorney General or its deputy to review the detention decision every six months. Suspected or non-deportable aliens might still be detained without trial or based on mere suspicion for an indefinite period of time.

(6) The bill allows the detention and deportation of people engaging in innocent associational activity, i.e. guilt by association. For example innocent people can be arrested, detained and deported for providing lawful assistance to groups that are not even designated by the Secretary of State as terrorist organizations, but instead have engaged in vaguely defined "terrorist activity" sometime in the past. To avoid deportation, the immigrant

should be increased; statues of limitations for terrorist offenses should be extended or eliminated. 
is required to prove a negative, i.e. that he or she did not know, and should not have known, that the assistance would further terrorist activity.

(7) The broad definition of terrorism might include Operation Rescue, Greenpeace, and even the Northern Alliance fighting the Taliban in northern Afghanistan.

Feingold was also not pleased to the intense pressure asserted and high handed tactics employed first by the Administration and later by his own party to speed up the legislative process and otherwise forced him to consent to the Act. In Feingold's own word:

"When the original Ashcroft anti-terrorism bill came in, they wanted us to pass it two days later. I thought this thing was going to be greatly improved. They did get rid of a couple of provisions, like looking into educational records. But there were still twelve or thirteen very disturbing things, and I thought, OK, we'll take care of this. But then something happened in the Senate, and I think the Democratic leadership was complicit in this. Suddenly, the bottom fell out. I was told that a unanimous consent agreement was being offered with no amendments and no debate. They asked me to give unanimous consent. I refused. The Majority Leader came to the floor and spoke very sternly to me, in front of his staff and my staff, saying, you can't do this, the whole thing will fall apart. I said, what do you mean it'll fall apart, they want to pass this, too. I said, I refuse to consent. He was on the belligerent side for Tom Daschle. And everybody said they were surprised at his remarks. Reporters thought it was so unlike him. And it is unlike him.

One of the interesting stories in this-and this is one that a lot of progressives don't want to hear, but it's the truth-is that John Ashcroft gave me a call and said, what are your concerns? And I told him my concerns about the computer stuff and sneak and peek searches. He said, you know, I think you might be right. The White House overruled him, which is a fundamental point here. Anyone who wants to focus their fire on Ashcroft is missing the point. This is the Bush Administration. Ashcroft is its instrument. What happened in the Senate was that even 
though the Attorney General was going to allow these changes to make it moderately better, the Administration insisted, and Daschle went along with pushing this through. I finally got to offer the amendments late at night, and I got up there and I made my arguments. And a lot of Senators came around to me, who, of course, voted for the bill, and said, you know, I think you're right. Then Daschle comes out and says, I want you to vote against this amendment and all the other Feingold amendments; don't even consider the merits. This was one of the most fundamental pieces of legislation relating to the Bill of Rights in the history of our country! It was a low point for me in terms of being a Democrat and somebody who believes in civil liberties." 191

\section{V \\ Conclusion}

This article is part of a larger research project about the "making" of the USA PATRIOT ACT: when, what, how and why the ACT came into existence. This article - "Legislative Process and Dynamics" - is mainly concerned with questions of when, what and how, leaving the issues of why to a later article. ${ }^{192}$ In the process, we discovered that the legislative process was hurried and flawed. The ACT was passed with little Congressional scrutiny and still less public input. For example, the ACT became law without the citizens being fully aware ${ }^{193}$ of its nature, purpose and impact. ${ }^{194}$ This caused grave consequences with our political system

${ }^{191}$ Matthew Rothschild, "Russ Feingold interview," The Progressive magazine, May 2002. http://www.thirdworldtraveler.com/Politicians/Russ_Feingold.html

192 See Author, "The Making of USA PATRIOT ACT: "Legislative Climate and Political Forces." (On file with author).

193 The USA PATRIOT ACT was not widely known, before, and in some quarters, long after it became law. The National news agencies and wire syndicate that inform citizens, define issues, provide perspective and establish frame of reference, did not see fit to report upon the ACT. See "Analysis of the Nightly News Glossing Over Anti-Terrorism Act" 8th Day Center for justice http://www.8thdaycenter.org/092801.html (Both ABC and NBC did not give the USA PATRIOT ACT the coverage it was due. Only ABC has a short segment on 9/25/01 warning that that proposed anti-terrorism law: ""give the government more power to spy on Americans here at home, monitor internet use with little oversight from a judge, lock up immigrants whom the government says might be a threat to national security without presenting evidence.") 
First to observe is that the ACT raised grave concerns and caused much alarm with the general public and affected groups. ${ }^{195}$ For example, notwithstanding the fact that Section 215 of the Patriot Act has rarely been invoked, library patrons feared that their reading habits were constantly being monitored. ${ }^{196}$ More tellingly, Senator Feinstein reported that her office has received 21,434 anti-Patriot Act letters, but less than half cited USA PATRIOT ACT provisions as a basis of complaint. ${ }^{197}$ The citizens knew something was wrong with the government's draconian anti-terrorism measures by was not able to articulate the sources of problems.

The commentators ${ }^{198}$ and librarians ${ }^{199}$ likewise were at a loss as to the reach, scope and applicability of the ACT. This caused much anxiety and

${ }^{194}$ The public have a lot of misunderstanding about the USA PATRIOT ACT. "Don't fault the misunderstood Patriot Act," "Letter to Editor" Detroit Free Press, July 26, 2003 (Jeffrey G. Collins, U.S. Attorney Eastern District of Michigan, pointed out that the public oftentimes misconstrued the ACT. For example, they wrongly assumed that the investigative (surveillance) powers given to the government is a sharp departure from the past. Or, they erroneously blamed the ACT for allowing the "holding prisoners as "enemy combatants.") http://www.freep.com/voices/letters/ecoll26_20030726.htm

195 Judging by public surveys, the public was hardly concerned much less alarmed with any loss of civil liberties, when the Act was passed. Majority of the citizen, until very recently, think that it is right and proper to allow the government to have more power to fight terrorism at the expensive of civil liberties. But "ignorance" and "misunderstanding" do breed concerns and alarms, especially when the fear of terrorism subside after $9 / 11$.

${ }^{196}$ Nat Hentoff, "Big John wants your reading list," The Village Voice. Mar 5, 2002. Vol. 47 (9); p. 27 (1 page) (The public is not informed and aware of the extent of government powers.)

${ }^{197}$ Susan Schmidt, "Patriot Act Misunderstood, Senators Say Complaints About Civil Liberties Go Beyond Legislation's Reach, Some Insist," Washington Post Wednesday, October 22, 2003; Page A04. (At a Senate Judiciary Cmte. oversight hearing (Oct. 21, 2003) Senators expressed concerns that the public has been misinformed about scope and reach, implementation and utility of the Act.). Watch, Sen. Orrin Hatch (R-UT) chairs a Senate Judiciary Cmte. hearing on the adequacy of federal laws for responding to and preventing acts of terrorism at C-Span on Tuesday, Oct. 21, 2003)

198 One commentator defended Section 215 by noting: "The "secret court" is the Foreign Intelligence Surveillance Court, which has existed for a quarter-century. To even get within the ambit of the court, probable cause must be demonstrated that the surveillance involves an agent of a foreign government or power." Bob Rob, "Shrill critics stealing Patriot Act debate," (September 21, 2003).

(http://www.azcentral.com/news/opinions/columns/articles/0921robb21.html In fact, the USA PATRIOT ACT amended the FSIA "probable cause" requirement. Under the ACT, 
constellation. $^{200}$ For example, librarians were puzzled as to whether they were allowed to consult lawyers before complying with a Section 215 order, ${ }^{201}$ or how best to reconcile librarians' professional-ethical responsibilities to protect privacy and their legal duties to release client information under the ACT. ${ }^{202}$ More tellingly, a national survey conducted in December 2001 - January 2002 showed that librarians' awareness and understanding of the USA PATRIOT ACT to be extremely low. Barely $50 \%(57.7 \%)$ have "read or heard" about the ACT immediately after it was passed. Correct understanding of different issues about the ACT ranged from a low of $20.8 \%$ (allow executive of warrant to be delayed for consultation of lawyer) to a high of $47.6 \%$ (allow access to record without warrant). ${ }^{203}$

a Section 215 order can be now be obtained by a certification to the court of relevancy of information needed to an on going terrorist investigation, without the need of demonstrating "probable cause" showing that the surveillance involves an agent of a foreign government or power.

${ }^{199}$ Estabrook, Leigh S. "Public Libraries' Response to the Events of September 11th, A National Survey Conducted by the Library Research Center at the University of Illinois Graduate School of Library and Information Science." January 22, 2003. Library Research Center, Graduate School of Library and Information Science, University of Illinois at Urbana Champaign. January 22, 2003

http://www.lis.uiuc.edu/gslis/research/national.pdf

${ }^{200}$ Rene Sanchez, "Librarians Make Some Noise Over Patriot Act Concerns About Privacy Prompt Some to Warn Patrons, Destroy Records of Book and Computer Use," Washington Post Thursday, April 10, 2003; Page A20

${ }^{201}$ Is calling the lawyer for help, not a prohibited disclosure under the USA PATRIOT ACT?

20248 states have protective library confidentiality and privacy law. The provisions of the law usually run counter to Section 215 of the Patriot Act. For example, Calif. Gov't. Code $\$ 6254$ and $\S 6267$ (2001). The library may not disclose these records except to a) staff within the scope of administrative duties, b) with written consent from the patron, or c) by order of the appropriate superior court.

${ }^{203}$ Estabrook, Leigh S. "Public Libraries' Response to the Events of September 11th, A National Survey Conducted by the Library Research Center at the University of Illinois Graduate School of Library and Information Science." January 22, 2003. Library Research Center, Graduate School of Library and Information Science, University of Illinois at Urbana Champaign. January 22, 2003 http://www.lis.uiuc.edu/gslis/research/national.pdf 
The pubic were further confused and aggrieved when the government, in order to "mollify" the public, ${ }^{204}$ mischaracterized the intent and purpose, ${ }^{205}$ reach and scope, ${ }^{206}$ and impact and effect of the ACT.

For example, U.S. Attorney for Alaska testified before a state Senate Committee: "[T] here is concern that under the PATRIOT Act, federal agents are now able to review library records and books checked out by U.S. Citizens... If you read the Act, that's absolutely not true... It can't be for U.S. citizens." In fact, Section 215 of the USA Patriot makes clear that "U.S. persons" - a term referring to citizens and some non-citizens alike -can have their record seized by the FBI with a FISA order.

Mark Corallo, Justice Department Spokesperson, spoke to the Bangor (ME) Daily News: "For the FBI to check on a citizen's reading habits....it must convince a judge "there is probable cause that the person you are seeking the information for is a terrorist or a foreign spy." In fact, Section 215 of the

204 “Interested Persons Memo on Congressional oversight of the USA PATRIOT Act and Department of Justice anti-terrorism policies - DOJ's dismissive response on civil liberties," ACLU Memo, dated June 4, 2003. ("DOJ has been deceptive in describing the scope of the powers it has been granted, apparently to mollify widespread public concern") http://www.aclu.org/SafeandFree/SafeandFree.cfm?ID=12812\&c=206 205 "RIGHTS AND THE NEW REALITY; Telemarketer Terrorists?" Los Angeles Times California Metro; September 13, 2003. Part 2; Page 10 (476 words) (The USA PATRIOT ACT was being used to investigate common criminals, e.g. telemarketers accused of swindling elderly consumers, a lawyer accused of stashing stolen funds in a Belize bank account and various drug dealers. This is contrary ultimate purpose of th ACT original intent of the legislators, and avowed promise of the Department of Justice.) ${ }^{206}$ Maine Civil Liberty Union Executive Director, Louise G. Roback, wrote a letter on April 16, 2003 to Senator Olympia Snowe complaining of FBI spokesperson's untruthful characterization of the USA PATRIOT ACT when responding to a Bangor Daily News article: "Calais library fights Patriot Act" (April 1, 2003) about Calais Free Library's opposition to the USA PATRIOT Act. Deputy Director Corallo's misrepresentation was reported in "Official counters Patriot Act critics." On April 9, the Bangor Daily News printed an editorial critiquing Justice Department misstatements. See "MCLU Demands Truth From Justice Department," MCLU ("We are concerned that Deputy Director Corallo provided false information concerning the powers of the Justice Department under the USA PATRIOT Act to the public.") http://www.mclu.org/calais letter 041603.htm See also Net Hentoff, "Op-ed: The state of our liberties," Washington Post Aug. 25, 2003. (The government put a spin of USA PATRIOT ACT.) http://www.washtimes.com/op-ed/20030824-110950-4866r.htm 
USA Patriot Act allows the government to obtain materials like library records without probable cause. ${ }^{207}$

The government's failure to provide for timely, responsive and accurate information over its enforcement policy (e.g., under what circumstances would Section 215 powers be invoked? ${ }^{208}$ ) and practices (e.g., how often has Section 215 powers been invoked ${ }^{209}$ ) generated wide spread anxiety and generated fear, ${ }^{210}$ leading to personal resentment, individual protests and collective movements across the United States. ${ }^{211}$ As a keen supporter of

${ }^{207}$ See "Reports: Government Missteps After Sept. 11," Summer 2003.ACLU of Northern California. http://www.aclunc.org/aclunews/news0309/reports.html Both the government and ACLU have accused each other of misleading the public. For ACLU's allegations, see Seeking Truth From Justice: PATRIOT Propaganda - The Justice Department's Campaign to Mislead The Public About the USA PATRIOT Act (ACLU, July 2003) ("The Justice Department's repeated assertion that the USA PATRIOT Act's surveillance provisions cannot be used against U.S. citizens. In fact, the surveillance provisions are applicable to citizens and non-citizens alike.”) http://www.aclu.org/Files/OpenFile.cfm?id=13098 The DOJ's answer to "Seeking Truth From Justice" is the DOJ's "Dispelling the Myths" on Life and Liberty web. ("Myth: The ACLU claims that the Patriot Act "expands terrorism laws to include "domestic terrorism' which could subject political organizations to surveillance, wiretapping, harassment, and criminal action for political advocacy."... Reality: The Patriot Act limits domestic terrorism to conduct that breaks criminal laws, endangering human life. "Peaceful groups that dissent from government policy" without breaking laws cannot be targeted." (Emphasis in the original) http://www.lifeandliberty.gov/subs/u myths.htm ${ }^{208}$ Eric Lichtblau, "Patriot Act's reach has gone beyond terrorism," Seattle Times September 28, 2003 (Government is using the USA PATRIOT ACT to investigate all kinds of crimes: suspected drug traffickers, white-collar criminals, blackmailers, child pornographers, money launderers, spies and corrupt foreign leaders.)

${ }^{209}$ The DOJ chose to answer only 28 of the 50 questions posed by the House Judiciary Committee by letter of July 13, 2002. See letters to Congress on implementation of the USA PATRIOT Act, dated July 26, August 26, and September 20, 2002. http://www.fas.org/irp/news/2002/10/doj101702.html

${ }^{210}$ Eric Lichtblau (NYT), "Demand for library records? Zero," Deseret Morning News (Salt Lake City) Pg. A02, September 19, 2003, Friday (872 words) (Emily Sheketoff, executive director of the Washington office of the American Library Association observed: "If the Justice Department had been more forthcoming with the public ... this high level of suspicion wouldn't have developed. But they've been fighting for two years not to tell people what they were doing, and that left a lot of people wondering what they had to hide."

${ }^{211}$ Emily Sheketoff, executive director of the Washington office of the American Library Association aptly observed: "If the Justice Department had been more forthcoming with the public, this high level of suspicion wouldn't have developed. But they've been fighting for two years not to tell people what they were doing, and that left a lot of people 
Bush administration, Representative Bob Barr, has occasion to observe: "The administration has not been at all forthcoming since then in explaining in a clear and open way how that act would be used and is being used. The lack of being forthcoming about discussing that has bothered me." 12

Finally, the Attorney General Ashcroft's farcical justification ${ }^{213}$ and inept defense of Act ${ }^{214}$ infuriated the Act's die hard opponents and alienated the administration's core supporters. ${ }^{215}$ For example, Attorney General Ashcroft was openly contemptuous of the law makers' rightful criticism of Bush administration's anti-terrorism initiatives: "To those who scare peace-loving people with phantoms of lost liberty, my message is this: Your tactics only aid terrorists, for they erode our national unity and diminish our resolve They give ammunition to America's enemies and pause to America's

wondering what they had to hide." Eric Lichtblau, "Patriot Act debate needless, Ashcroft says," New York Times September 18, 2003. http://www.chron.com/cs/CDA/ssistory.mpl/nation/2108405

${ }^{212}$ Michael Tomasky, "Strange Bedfellows: Conservative civil libertarians join the fight," The American Prospect Vo. 14, no. 8, September 1, 2003.

http://www.prospect.org/print/V14/8/tomasky-m.html

213 "Civil libertarians criticize FBI rules; They fear the terrorism crisis is being used as a cover to erode personal freedoms," The Associated Press. The Grand Rapids Press May 31, 2002. p. A.3. (James X. Dempsey, deputy director of the Center for Democracy and Technology observed: "They are using the terrorism crisis as a cover for a wide range of changes, some of which have nothing to do with terrorism." Dempsey predicted that the power will be used for "every other type of investigation the FBI does.")

214 "ASHCROFT'S ENDLESS ATTACKS DIMINISH OFFICE," Dayton Daily News (Ohio), August 11, 2003, Monday, CITY EDITION, EDITORIAL; Pg. A6 (540 words) (The Attorney General was best remembered for his fear-mongering and vindictive antics: "To those who are alarmed, or who question or criticize his approach, Mr. Ashcroft has said: "Your tactics only aid terrorists, for they erode our national unity and diminish our resolve. They give ammunition to America's enemies and pause to America's friends.")

${ }^{215}$ Myriam Marquez, "BLAME GAME: THE 9-11 BUCK SHOULD STOP WITH ASHCROFT," Sentinel Columnist. Orlando Sentinel. Jun 4, 2002. p. A.9 ("To Ashcroft, it seems, the answer to fighting terrorism is cracking down on Americans' civil liberties and immigrants' basic human rights.") More recently, the Attorney General described librarian's concerns with the Patriot Act "breathless reports and baseless hysteria." See Prepared Remarks of Attorney General John Ashcroft "The Proven Tactics in the Fight against Crime" Washington, D.C., September 15, 2003. See also ERIC LICHTBLAU, "Ashcroft Mocks Librarians and Others Who Oppose Parts of Counterterrorism Law," New York Times, September 16, 2003. http://www.nytimes.com/2003/09/16/politics/16LIBR.html 
friends." ${ }^{216}$ He was publicly dismissive of librarians' legitimate concern with the erosive impact of Patriot Act on library privacy: "The charges of the hysterics are revealed for what they are: castles in the air built on misrepresentation, supported by unfounded fear, held aloft by hysteria." 217 Last not least, Barbara Comstock, a spoke person the Department of Justice, was loudly belittling local grassroots communities' genuine anti-Patriot sentiments:

"Some of the different ordinances that have passed throughout the country, about 45 percent of them, almost half, are either in cities in Vermont, very small populations, or in sort of college towns in California. It's in a lot of the usual enclaves where you might see nuclear-free zones or, you know, they probably passed resolutions against the war in Iraq."

The statement drew predictable and angry response from Senator Leahy:

"It is unfortunate that the Justice Department felt it appropriate to ridicule these grass-roots efforts to participate in an important national dialogue. The opportunity to engage in public discourse is one of the essential rights of Americans, and I am proud that Vermont towns are among those dedicated to thinking about and acting on these important issues. More importantly, the concerns expressed in my home state are being echoed by Americans in all 50 states. These communities represent millions upon millions of Americans, not just a few liberty-and-privacy-conscious Vermonters, as the Justice Department has insinuated. Impugning Vermonters, dedicated librarians and United States Senators for asking questions and raising concerns does not advance the debate or instill public confidence in the Ashcroft Justice Department's use of the vast powers it wields. In fact, it achieves the opposite." 218

\footnotetext{
${ }^{216}$ See Testimony of Attorney General John Ashcroft Senate Committee on the Judiciary December 6, 2001.

http://www.usdoj.gov/ag/testimony/2001/1206transcriptsenatejudiciarycommittee.htm

${ }^{217}$ Ashcroft later explained to ALA that he was not directing his comments to the librarians, but the ACLU.

${ }^{218}$ Statement of Senator Patrick Leahy, Ranking Member, "Senate Committee on the Judiciary Hearing on Protecting Our National Security from Terrorist Attacks: A Review
} 
As a result of above observed public confusion and anxiety, government zealotry and ineptitude, the USA PATRIOT ACT continues to draw vociferous criticism ${ }^{219}$ and fiery protests, ${ }^{220}$ four years after its passage. ${ }^{221}$ Many of the issues that should and could have been carefully investigated and seriously discussed, ${ }^{222}$ such as the impact and implications of the USA

of Criminal Terrorism Investigations and Prosecutions." October 21, 2003. http://www.senate.gov/ judiciary/member statement.cfm?id=965\&wit id=2629

${ }^{219}$ By far the most vocal and prolific commentator is Nat Hentoff, a columnist with the Village voice. For his brief Bio. See "Nat Hentoff" Washington Post. (1998)

http://www.washingtonpost.com/wp-srv/politics/opinions/hentoff.htm For a sample of his critique of the Patriot Act, see "Ashcroft Out of Control: Ominous Sequel to USA Patriot Act," Village Voice February 28th, 2003 and "Crossing Swords With General Ashcroft: Where Is Our Bill of Rights Defense Committee?" truthout December, 20., 2002 (Citing Thomas Jefferson: "The spirit of resistance to government is so valuable on certain occasions, that I wish it to be always kept alive." (letter to Abigail Adams, February 22, 1787), he called for active grassroots resistance to the USA PATRIOT ACT.) There are to be many others across the United States and from the very beginning. See "Opinion: The Patriot Act is a threat," Deseret Morning News (Salt Lake City), OPINION; Pg. A15, August 27, 2003, Wednesday (479 words) (USA PATRIOT ACT was compared with "general search warrants" used by British customs agents during American Revolution.)

${ }^{220}$ The Attorney General's 16 states and 18 cities road show to promote the USA PATRIOT ACT was met with protesters everywhere the Attorney General went. Diane Urbani, "Patriot Act undercuts King's dream, Utahn says," Deseret Morning News (Salt Lake City, August 29, 2003. Friday (762 words) (The Attorney General was met with 200 protesters.) [Another account put it at 150. See Angie Welling and Jennifer Dobner, "Act called vital tool in war on terror." Deseret Morning News (Salt Lake City), WIRE; Pg. A01, August 26, 2003, Tuesday (1008 words)].

${ }^{221}$ See Leonard Kniffel, "CPL head's comments provoke outrage," American Libraries. Jan 2002. Vol. 33, Iss. 1; p. 30 (Librarian should never surrender library information except by court order and with judicial process.) "EDITORIAL: Tempest in a teapot," Las Vegas Review - Journal. Jun 3, 2002. p. 6.B (It is necessary to trade liberty for security in time of crisis.) ${ }^{222}$ See GREG BLUESTEIN, "University professors: Country must not overreact," redandblack.com (University of Georgia student newspaper) September 12, 2001. (Notwithstanding the catastrophic nature and tragic consequences of 9/11 attack, the nation should not overact.). CATO analyst Timothy Lynch echoed many other others that we should not react to $9 / 11$ in a knee jerk fashion. Looking back in history, Lynch observed that all of the country's effort to fight terrorism was reactionary in nature and laboring under a crisis mentality. "Government officials typically respond to terrorist attacks by proposing and enacting "antiterrorism" legislation." The Feb. 26, 1993 bombing of the World Trade Center gave us the Terrorism prevention and Protection Act of 1993. The April 19, 1995 bombing of the Murrah Federal Building Bombing 
PATRIOT ACT on civil liberties, are now only beginning to be seriously addressed by the lawmakers, ${ }^{223}$ critically debated by the public, ${ }^{224}$ and systematically analyzed by the Courts. ${ }^{225}$

The voices of dissents could be heard from interested citizens and concerned activists across the Nation, from California to New Work, Wisconsin to

Oklahoma led to the passage of Comprehensive Terrorism Prevention Act of 1995. Lynch argued that "The cycle: Terrorist Attack and "Anti-Terrorism Legislation" must be stopped. Particularly, policy makers should refrain from legislation until they have time to study and deliberate upon four issues: (1) accountability; (2) history; (3) reality; (4) freedom. Timothy Lynch, "Breaking the Vicious Cycle: Preserving Our Liberties While Fighting Terrorism,” Cato Policy Analysis No. 443, June 26, 2002.

http://www.cato.org/pubs/pas/pa443.pdf

${ }^{223}$ See "Ron Paul Applauds Congressional Restrictions on Patriot Act," The Office of Rep. Ron Paul (R-TX), July 25, 2003. http://www.antiwar.com/paul/paul72.html (Reprint)

${ }^{224}$ See Editorial: "Privacy in time of crisis," Orange County Register. Oct 1, 2001. p. Edit; Chuck McGinness, "LIBRARIAN'S POST-ATTACK REPORT TO FBI SPARKS PRIVACY DEBATE," Palm Beach Post, Dec 1, 2001, p. 1.B; Anonymous, "FBI spies on suspect at library," American Libraries. Dec 2001. Vol. 32, Iss. 11; p. 24 (2 pages); Pat Schneider, "NEW U.S. LAW AIDS SNOOPING ON READERS; LOCAL BOOKSTORES, LIBRARIES WORRY," Madison Capital Times. Dec 25, 2001. p. 1.A; Nat Hentoff, "Big Brother in the library; Patriot Act turns librarians into FBI informants," THE WASHINGTON TIMES. Feb 25, 2002. p. A.21; Nat Hentoff, "Big John wants your reading list," The Village Voice. Mar 5, 2002. Vol. 47, Iss. 9; p. 27 (1 page ${ }^{225}$ Carl Carlson, "Patriot Act Provision Challenged in Court," e-Week July 30, 2003 http://www.eweek.com/article2/0,4149,1208043,00.asp For the text of complaint to the first ever legal complaint filed to challenged Section 215 of the USA PATRIOT ACT, see Muslim Community Ass'n of Ann Arbor, et al. v. Ashcroft No. 03-72913 (E.D. Mich. July 30, 2003)., "Complaint for Declaratory and Injunctive Relief." The complaint alleged that Section 215 of the Patriot Act unconstitutional in violating First, Fourth, Fifth Amendments of the U.S. Constitution ("Preliminary Statement," para. 1, 2.) http://news.findlaw.com/cnn/docs/aclu/mcaa2ash73003cmp.pdf 
Florida, on campaign trails ${ }^{226}$ and in public forums. The dissenters included republican and democrats, ${ }^{227}$ civil libertarians and conservatives. ${ }^{228}$

Activists mobilized grassroots movements to establish "Civil Liberties Free Zone"229 in open defiance of the Patriot Act. ${ }^{230}$ The Congress worked with afflicted groups and aggrieved citizens to pass law to limit the actual harm and contain the potential fallout of the Patriot Act, including denying money for enforcement, ${ }^{231}$ requiring oversight into implementation, ${ }^{232}$ and limiting

${ }^{226}$ BILL ADAIR, "Graham quiet about his role on Patriot Act: On the campaign trail, he isn't bringing up that he co-wrote the controversial bill in the Senate," St. Petersburg Times. June 14, 2003. (Senator Graham did not reveal his role in drafting part of the USA PATRIOT ACT as former chairman of the Senate Intelligence Committee. Governor Dean publicized the fact that he was opposed the Act as unconstitutional: "It can't be constitutional to hold an American citizen without access to a lawyer... Secondly, it can't be constitutional for the FBI to be able to go through your files at the library or the local video store, to see what you've taken out in the last week, without a warrant." http://www.sptimes.com/2003/06/14/Worldandnation/Graham quiet about hi.shtml

${ }^{227}$ On May 21, 2003, Alaska's Senate unanimously approved the country's second statewide anti-Patriot resolution entitled: "HJR 22: PATRIOT ACT AND DEFENDING CIVIL LIBERTIES" as a bipartisan effort. It passed the State Senate unanimously and the House 32-1. http://www.akrepublicans.org/coghill/23/spst/cogh hjr023.php

${ }^{228}$ Nicholas Confessore, "In Bed with Bob Barr: How conservatives became the ACLU's best friends," American Prospect. Vol. 12 (19) Nov. 5, 2001

http://www.prospect.org/print/V12/19/confessore-n.html

${ }^{229}$ As of September 18, 2005, 394 Resolutions Upholding Civil Liberties and Rights have been passed in communities across the U.S. affecting $61,947,419$ people: being

Community resolutions: 387 and State resolutions: 7. http://www.bordc.org/index.php

${ }^{230} \mathrm{http}$ ://www.bordc.org/states.htm

231 Republican Congressperson Butch Otter from Idaho introduced an amendment to a House Appropriations bill (HR 2799) to remove funding from the Department of Justice to conduct "sneak and peek" searches. The vote for Otter's amendment was 309-118 with widespread bi-partisan support. See also Congressman Bernie Sanders (I-VT)'s effort in offering an amendment to the Commerce, Justice, State and Judiciary Appropriations Bill of 2004 to cut off Justice Department funding for searches of bookstore and library records under Section 215 of the USA Patriot Act. It is co-sponsored by John Conyers, Jr. (D-MI) and C.L. "Butch" Otter (R-ID).

232 On February 25, 2003, Senators Leahy, Grassley and Specter introduced S. 436, the "Domestic Surveillance Oversight Act of 2003." http://www.acluor.org/issues/terrorism/FISA oversightbill.htm On June 11, 2003, Representative Hoeffel and others introduced H.R. 2429, the "Surveillance Oversight and Disclosure Act of 2003. " The bills amend the Foreign Intelligence Surveillance Act of 1978 to improve the administration and oversight of foreign intelligence surveillance." http://www.fas.org/irp/congress/2003_cr/hr2429.html 
the applicability of the Patriot Act. ${ }^{233}$ For example, on March 6, 2003, House Representative Sanders (I-Vermont) introduced the "Freedom to Read Protection Act of 2003" (HR 1157) in the House "To amend the Foreign Intelligence Surveillance Act to exempt bookstores and libraries from orders requiring the production of any tangible things for certain foreign intelligence investigations, and for other purposes.") HR1157 was cosponsored by 129 bipartisan cosponsors. It was support by 20 newspapers editorial boards, 40 library, book, publishing industry, and civil liberty groups.

On May 23, 2003, Sen. Barbara Boxer (D-CA) introduced that "Library and Bookseller Protection Act" (S. 1158) in the Senate "To exempt bookstores and libraries from orders requiring the production of tangible things for foreign intelligence investigations, and to exempt libraries from counterintelligence access to certain records, ensuring that libraries and bookstores are subjected to the regular system of court-ordered warrants."234

On July 31, 2003 Senator Russell D. Feingold (D-WI) introduced "The Library, Bookseller, and Personal Records Privacy Act" (S. 1507) introduced on July 31, 2003 "To protect privacy by limiting the access of the Government to library, bookseller, and other personal records for foreign intelligence and counterintelligence purposes, ${ }^{, 235}$

July 31, 2003 Sen. Lisa Murkowski (R-AK) introduced "Protecting the Rights of Individuals Act (S.1552) in the Senate "To amend title 18, United States Code, and the Foreign Intelligence Surveillance Act of 1978 to strengthen protections of civil liberties in the exercise of the foreign intelligence surveillance authorities under Federal law, and for other purposes." 236

${ }^{233}$ HR 1157 IH. 108th CONGRESS. 1st Session. HR 1157. http://www.fas.org/irp/congress/2003 cr/hr1157.html See "The Sanders-Otter-Conyers Amendment to the Commerce, Justice, State, and Judiciary Appropriations Bill of 2004" http://listproc.ucdavis.edu/archives/ncal-lib/ncal-lib.log0307/att-0017/01 talking points on the Sanders-Otter-Conyers C J S amndt.doc ${ }^{234} \mathrm{http} / / \mathrm{www}$. fas.org/irp/congress/2003 cr/s1158.html $235 \mathrm{http}: / /$ www.theorator.com/bills 108/s1507.html

236 Specifically the Act provides: "Sec. 4 would....return the standards for the FBI to get orders from the FISA Court to the standards that applied pre-USA PATRIOT." "Sec. 4(b) would clarify that a library shall not be treated as a wire or electronic communication service provider for purposes of 18 U.S.C. 2709 , so that a library cannot be required to turn over Internet usage records (including e-mail) about its patrons." "Sec. 6(c) would 
impose a specific limitation on what aspects of electronic communications could be captured with a pen/trap order" http://www.fas.org/irp/congress/2003 cr/s1552.html For other legislative effort to scale back the scope and impact of the Patriot Act, see "Proposed Legislation" Bill of Rights Defense Committee, http://www.bordc.org/legislation.htm (Visited October 12, 2003) 